\title{
Economics of Genesis: On the Institutional Economic Deciphering and Reconstruction of the Stories of the Bible*
}

\author{
Sigmund Wagner-Tsukamoto** \\ Management Centre, University of Leicester, UK
}

\begin{abstract}
The article traces in the book of Genesis (1) theoretical and (2) methodic elements of an institutional economics: (1a) the idea of capital contribution-distribution interactions as model of social exchange; (1b) the idea of incentive structures as model of an institutional regulative for social exchange; (1c) the practical-normative goal of pareto-superiority (mutuality of gains) as desired interaction outcome; (2a) the methodic concept of conflicting and common interests in contribution-distribution interactions (the idea of a dilemma structure, or "war of all", as Hobbes called it); and (2b) the methodic concept of selfinterested choice behaviour (the homo economicus, or "methodological individualism" as Hayek referred to it). On these grounds, Genesis is deciphered and reconstructed in institutional economic terms. The article develops and explores the hypotheses (i) that the stories of Genesis reflect an intense interest and attempt to come to terms with the institutional problem of how to ensure cooperation in social interactions, and (ii) that the stories of Genesis address the institutional problem in economic terms, examining social conflict as capital contribution-distribution interactions, advising on the pareto-effectiveness of conflict resolution in relation to incentive structures, and methodically grounding analysis in the ideas of the dilemma structure and the homo economicus. Such an economic reconstruction of Genesis questions conventional theological suggestions on the role and extent to which the Bible invokes metaphysical concepts and metaphysical intervention for analyzing and solving social problems.
\end{abstract}

\section{[footnote 1]}

* This paper is a revised version of Discussion Paper No. 2000/01, Management Centre/Dept. of Economics, University of Leicester, UK, January 2000 (ISSN 1461-6017).

[footnote 2]

** Dr. Sigmund Wagner-Tsukamoto, Management Centre, Ken Edwards Building, University Road, University of Leicester, Leicester LE1 7RH, UK. Email: saw14@le.ac.uk 


\section{CONTENTS}

\section{Economics of Genesis: On the Institutional Economic Deciphering and Reconstruction of the Stories of the Bible}

1. Excursus: Is Social Science Research on the Bible 'Permitted'?

2. The Institutional Economic Approach Outlined

2.1. Key Theoretical Ideas of an Institutional Economic Reconstruction

2.2. Key Methodic Ideas of an Institutional Economic Reconstruction

3. An Institutional Economic Reconstruction of Genesis

3.1. Biblical Capital Contribution-Distribution Conflicts and Pareto-superiority as Desired Outcome of Conflict Resolution: In Search of the Genesis of Wealth for a Community of Nations

3.2. A Methodic Interpretation of Defection in Paradise: The Biblical Analysis of Contribution-Distribution Conflicts Through the Ideas of the Dilemma Structure and the Homo Economicus

3.3. Biblical Ordering and Conflict Resolution: Favouring Incentive Structures and Economic Ordering Rather Than Value Structures and Behavioural Ordering?

3.3.1. Genesis' Behaviourial Approach to the Institutional Problem: A Psychological Theological Contract Between God and Man and the Religiosity of the Individual as Institutional Regulative

3.3.2. Genesis' Exit From a Behaviourial-Theological Economics: The Birth of Israel and the Favouring of Economic Ordering as Mechanism for Institutional Regulation

4. Conclusions on the Economic Origins and the Economic Nature of Biblical Thought

\section{Bibliography}




\title{
Economics of Genesis: On the Institutional Economic Deciphering and Reconstruction of the Stories of the Bible
}

\author{
There is nothing new under the sun. Is there anything of which one can say, "Look! \\ This is something new"? It was here already, long ago; it was here before our time. \\ (Ecclesiastes 1:9-10)
}

The Bible is one of the oldest and most widely read documents of mankind's cultural heritage $^{1}$. Its very existence raises questions regarding its rationale and motivation. Theology refers in this respect to issues concerning the nature of God, the identity and nature of man, the nature of the world and, related, questions concerning the meaning of life (e.g. Tullock 1981: 1-3, 39-41, Lace 1972: 103-6, 115-18, Hodson 1967: 114-16). Besides such issues, it could be speculated that the Bible addresses, possibly first and foremost, a social purpose: namely the analysis and resolution of problems in social behaviour. As Brams (1980: 78) noted, the Old Testament reflects "... conflict piled upon conflict, with battles, war, and family feuds the norm rather than the exception". Possibly above all the Bible reflects an early documented attempt to analyze and solve the institutional problem of how to ensure cooperation in social interactions. The identification of such a suggested interest in the institutional problem does not (yet) differentiate a theological interpretation of the Bible from an economic one. Indeed, theological research on the nature of God, the nature of man, and the nature of social life frequently seems to be at least implicitly geared towards advising on the institutional problem. However, what differentiates a theological interpretation of biblical thought from an economic one as pursued in this paper is that ideas on social ordering and institutional mechanisms for resolving social conflict are reconstructed in scientific economic terms, by drawing on non-metaphysical and non-behavioural ideas. In particular, the idea of the institution - of social structures which can induce cooperation in social interactions - is interpreted by economics as "incentive structures" (or "governance structures" in Williamson's terminology) but not in a behavioural manner as value structures, such as shared cultural values, which in the case of theology are interpreted as religious belief systems that reflected godly wisdom. An economics aims at situational intervention via the (re)-design of 
incentive structures in order to remedy social conflict but not behavioural intervention with a claimed human condition, e.g. lacking religious belief, via a metaphysical instance.

The present paper argues (1) that the meaning of the Bible relates, above all, to the institutional problem, and (2) that the Bible reflects in large degrees an institutional economic treatise; basic questions of cooperation and conflict resolution being approached (a) as questions of wealth creation for all interacting decision-makers (aiming at 'paretosuperiority') by analyzing (b) social behaviour as interactions over capital contributions and capital distributions, and (c) institutions as incentive structures. In methodical perspective it is suggested that the Bible grounded the analysis of the institutional problem (d) in the idea of the dilemma structure (the "war of all" as Hobbes called it) and (e) in the idea of the homo economicus. The key thesis so developed and analyzed is that the Bible draws on a conceptual logic which mirrors the institutional economic approach, as pioneered by Hayek, Buchanan, Coase, North, and Williamson ${ }^{2}$, which means a body of thought that aims at the resolution of cooperation problems by treating them in rational scientific terms. On this ground, the paper develops a set of theoretical hypotheses regarding the institutional economic nature of Bible stories. In particular, it is suggested that the Bible analyzed succeeding/failing cooperation not in relation to the human condition (as conventionally proposed by theology) but in relation to a systemic, situational condition, namely in relation to the way incentive structures are set up. The paper develops a set of methodical hypotheses, namely that the Bible's depiction of man as self-interested (even as cheating, wicked, evil, etc.) as well the Bible's depiction of social life as dilemmatic interaction conflicts, as already discussed at the very outset of Genesis through the original sin in the garden of Eden story, should "only" be interpreted in a heuristic, methodic sense but not in an empiricalbehavioural one (as conventionally done by theology).

The institutional economic analysis of biblical thought pursued in this paper moves in its direction and scope away from micro-economic studies of religious behaviour, e.g. an economics of believing, charitable behaviour, church attendance behaviour, conversion behaviour, etc. (e.g. Smith 1999, Iannaccone 1998, 1995, Ensminger 1997, Hardin 1997, Raskovich 1996, or Kuran 1994). These studies were not interested in analyzing interaction problems (and the institutional problem) in general and biblical thought in particular. Also, the institutional economic approach taken in this paper diverges from previous economic 
analyses of Bible stories, such as a game theoretical analysis (Brams 1980), a scarcity-based interpretation (Gordon 1994, 1989, also Paris 1998), and a legal-economic analysis of Bible stories (Miller 1994, 1993a, 1993b). These studies touched upon issues which could be viewed as methodic and/or theoretical fragments of an institutional economic reconstruction of Bible stories as outlined by this article. They provide valuable source material and reference points to indicate the different type of economic analysis of Bible stories is pursued by the present paper and what different insights can thus be generated. It is suggested that an institutional economic reconstruction can accommodate and put into perspective Gordon's (1994, 1989) hypothesis that the Bible analyzed the problem of scarcity in human choice behaviour; Brams' (1980) hypothesis that biblical characters, including God, were rational economic game players; or Miller's (1994, 1993a, 1993b) hypotheses that the Bible analyzed economic aspects of animal sacrifices and of practices of oral contracting.

The article makes cautious claims that an institutional economic reconstruction gets closer to holding a "magic key" ${ }^{3}$ to some of the mysteries of the Bible, at least more so than theological studies and previous economic studies. The present paper differs in various respects from previous economic studies of the Bible, namely in its specific research focus and its vision and understanding of the economic approach, including the demarcation of economics from theology ${ }^{4}$ :

(i) Social problems depicted in Bible stories are coherently reconstructed by the present paper in scientific economic terms: as a reflection of the institutional problem understood as a capital contribution-distribution conflict which is induced by 'defective' incentive structures. Thus, social problems are reconstructed as a situational condition but not as a reflection of the human condition. Related, the present paper exits from a behavioural, theologically grounded economics, as explicitly subscribed to by Brams, Gordon, and Paris.

(ii) Game theory and rational choice theory, e.g. the ideas of the dilemma structure or the homo economicus, are only methodically aligned with Bible stories but not in a theoretical and/or empirical-behaviourial sense. The latter is explicitly done by Brams and Paris, and implicitly by Miller and Gordon. 
(iii) In practical-normative perspective, a resolution of social conflict is reconstructed by the present paper with regard to the idea of mutuality of gains ('pareto-superiority') as desired interaction outcome - the "wealth of a community of nations", as Genesis (35: 11, 48: 4, 19) referred to it. Previous economic studies of the Bible did not analyze this issue. Such a cooperation principle and further principles derived hereof are not too far away from religious ideals of sharing, solidarity, and social justice, although an institutional economics in the rational scientific tradition of the Enlightenment obviously would here proceed conceptually rather differently than theology or a theologically grounded economics.

(iv) A theologically grounded economics conceptualizes God as a metaphysical entity: an omnipresent and omnipotent personal God, who intervened with the resolution of the institutional problem. In contrast, an economics of the Bible, as pursued in this article, ultimately deciphers and reconstructs the idea of God (as far as it relates to issues of social ordering) in rational scientific terms; as a reference of the Bible to an economic principle of ensuring public good in social interactions ${ }^{5}$.

This latter issue of how to conceptualise the idea of God in an economic analysis of Bible stories leads to possibly contentious but, for an economics, of religion important methodic and theoretical questions. In an economics of religion, the idea "God" may have to be differently approached than by a theologically grounded economics, which ontologically interpreted "God" as a given, metaphysical entity, and related the stories of the Bible as a "religious, holy reality", as done by Brams (1980: 3-5, 169-170, 173), Gordon (1994: 22, 39, also 1989) and Paris (1998: 42), and by theology in general (See Tullock 1981:2, Spriggs 1972: 7, Hodson 1967: 4, Anderson 1966: 6). In particular, suggestions such as the ones put forward by Paris (1998: 42) are questioned by the present paper; that a coherent analysis of Bible stories in economic terms had to be grounded in a "literalist" theological approach ${ }^{6}$, treating the Bible as a holy text that reflected the word of God.

Possibly more so than previous theologically grounded economic studies of Bible stories, which hang on to certain theological assumptions and prerogatives, an institutional 
economic reconstruction, as detailed in the following, enables a conceptually coherent and integrative analysis of Bible stories. Particular strengths of the institutional economic framework applied in this paper are its conciseness and conceptual coherence which may rival a theological interpretation (and a theologically grounded economic interpretation) of Bible stories. At times, sociological and theological analysis of religion have been criticized for ad hoc-theorizing, lacking theoretical coherence and integration, and being driven by rather random and arbitrary interpretations (Iannaccone 1995: 78). The present paper suggests that metaphysical ideas can be reconceptualised by an institutional economics without the apriori postulation of certain pre-scientific concepts, deciphering and reconstructing them through the very methodic and theoretical elements that make up the institutional economic approach (See also Wagner-Tsukamoto forthcoming: Chapter 8). A metaphysical conceptualization of the idea of God and of God's role in resolving social conflict is probably only of interest to theology (and a behavioural, theologically grounded economics). However, such conceptualisations appear methodically and theoretically difficult to reconcile with a scientific research tradition (See also Hayek 1976: 170) - which would aim at conflict resolution through means of human intervention (in the case of economics, with incentive structures) but not by waiting for and relying on an omnipotent and omnipresent metaphysical entity to intervene as problem solver, as suggested by theology (e.g. Cohn 1981: 1, Lace 1972: 115-17). Thus, an economic analysis of the Bible can enquire rather differently about the basic nature and purpose of the Bible.

In the following, first the admissibility of economic research on the Bible is briefly reviewed. Second, the key elements of an institutional economic approach are outlined. Particular attention is paid to demarcating the methods of an (institutional) economics 'homo economicus' and 'dilemma structure' - from its elements of theory building and practical intervention - ideas like 'incentive structures', 'interactions over capital contributions and distributions', and the normative goal of mutuality of gains ('paretosuperiority'). Third, methodical, theoretical, and practical-normative elements of an institutional economics are traced in Genesis. The discussion analyzes how far economic versus non-economic concepts were drawn upon by Bible stories in their apparent analysis of the institutional problem. 


\section{Excursus: Is Social Science Research on the Bible 'Permitted'?}

This paper examines how far Bible stories can be coherently and comprehensively brought under a scientific economic scheme of analysis. The approach subsequently followed is grounded in an economics of religion rather than a religious, theologically grounded economics. The latter followed in the footsteps of theology and tried to integrate economic analysis with theological concepts. For instance, it would view the idea of God as a given metaphysical concept which should be beyond an economic conceptualisation, as suggested by Paris (1998: 42). In contrast, an (institutional) economics of religion can attempt, in the tradition of the Enlightenment, to deconstruct and reconstruct metaphysical ideas. Such an economic interpretation might attract criticism from theology and a theologically-oriented economics (and here the more so from orthodox, literalist, theological researchers) since it rethinks basic prerogatives, assumptions, and conceptualizations of theology, for instance, the analytical nature and status of ideas like 'God', 'original sin', the 'wickedness of man', etc.

Looking at the impressive body of research in a sociology of religion (See Stolz 1974: 36), the question regarding the permissibility of social science research on religion in general, and on the Bible in particular, may already seem to be answered. Still, there is a scarcity of economic research on the Bible and obvious difficulties exist between economists and theologians to understand each other's research - turmoil, even hooliganism is reported from one of the first conferences that was shared by theologians and economists (Brennan and Waterman 1994: 3-4). Two methodically grounded arguments are discussed in the following in order to question ontologically grounded and morally grounded criticism of an economic reconstruction of Bible stories.

It is generally accepted that Bible stories need interpretation. Nevertheless, historically, theology has fought hard on ontological grounds to prevent sciences from interpreting its claimed subject matter. For instance, once physicists and biologists began to analyze the origin of the world and the origin of life in a way which was apparently incompatible with the way theology then interpreted biblical thought, scientists faced stern opposition and confrontation ${ }^{7}$. As helpful as an ontological understanding of scientific, philosophical, or theological research may be for illustrating simply what a research program 
is about, e.g. the fall of stones could be said to be the physicist's; markets could be said to be the economist's; role behaviour could be said to be the sociologist's; God could be said to be the theologist's, etc., it is probably just as unhelpful for understanding the basic nature of research. In one way or another, the various social sciences, philosophy, and theology all research the same subject matter. For instance, a phenomenon like marriage has been successfully conceptualized and analyzed in the terms of theology, philosophy, psychology, sociology, or economics. The same could be suggested with regard to the institutional problem. What seemingly distinguishes different research programs may not be different subject matter so much as different ways of looking at subject matter, reflecting methodic differences of "approach" (Becker 1993: 385, 402, 1976: 5; implied by Friedman 1953). Such an understanding of research is in the first place methodically grounded rather than ontologically or phenomenologically. Leibniz and Kant pointed at such a methodic understanding of research early on, and the philosophy of science of Popper (1978) and Lakatos (1976) explained such an interpretation (Wagner-Tsukamoto forthcoming: Section 2.1, Suchanek 1994, Homann and Suchanek 1989: 72-73, 81; also Cassirer 1962: 4-5, $532-$ 533). On these grounds, findings from different research programs become compatible, i.e. once they are transcended for methodical differences of approach. In this respect, an economic interpretation of Bible stories does not directly compete with theological research and theologically grounded economic research on the Bible, in particular a theological interpretation of God as an omnipresent and omnipotent personal God. To some extent, questions regarding the ontological status of the idea 'god' in biblical thought could even be said to be irrelevant to the present paper, which interprets the idea 'god' as a conceptual component of the text 'Bible'.

Criticism of an economic interpretation of the Bible might come from another direction, too: It has been claimed that economics were a "dismal", "dehumanized" science since it projected, so it is claimed, a negative image of human nature and of social life. Such claims are voiced at times even by renowned economists like Williamson (1985: 391) or Simon (1976: xxi), or similarly Sen (1990: 25). It can be suggested (Homann and Suchanek 1989: $75,79,84$ ) that they may reflect a misunderstanding of the economic approach, mostly a misunderstanding of the methods of economic research as a reflection of an image of human nature and a world view, of 'real people' and 'real life'. Rather than in relation to its 
methodic tools, such as the homo economicus, economics' world view and image of human nature, and its moral status as a social science, may have to be assessed by focusing on its suggestions on theory building and practical intervention.

In general, the moral status of an (institutional) economics appears difficult to question: it aims to advise on solving social problems to the advantage of all interacting decision makers. Normative goals like mutual prosperity and increases in the wealth of nations, as Adam Smith put it, but not merely the increase of individual welfare, is aimed at. This reflects moral values like social justice, solidarity, or fraternity (Wagner-Tsukamoto forthcoming: Section 8.1, 2001). Indeed, if economics were not a moral science, which aimed at the generation of socially desirable outcomes, it would be difficult to comprehend why the moral philosopher Adam Smith, after decades of research in a behaviourial moral philosophy, ultimately should have favoured the economic approach to analyze social problems of modern society (Homann 1990: 4-5; see also Iannaccone 1998: 1465). This suggestion is reinforced by the present paper by outlining that biblical stories can be reconstructed as a body of thought which examines - for moral reasons - problems in social behaviour in economic terms. A reconstruction of biblical thought in economic terms may also encourage a reevaluation of economics' status as a moral science.

\section{The Institutional Economic Approach Outlined}

The subsequent discussion outlines a simple vision of the institutional economic approach. A conceptual scheme of theoretical-(practical) elements and of methodic elements is drawn upon: As theoretical-(practical) elements are discussed the ideas 'incentive structures', 'social interactions over capital utilization', and 'pareto-superiority/-inferiority'; as methodic elements are discussed the ideas 'dilemma structure' and 'homo economicus'. Figure 1 provides an overview (For details, see Wagner-Tsukamoto forthcoming: Chapter 2, 2001). In line with this framework, the stories of the Bible are deciphered and reconstructed in section 3. The suggested framework connects an understanding of the nature of scientific research to the works of Friedman, Buchanan, Becker, and Homann, who interpret the economic approach methodically rather than ontologically (Also Popper and Lakatos, see above), and 
an understanding of the conceptual nature of economic research to an institutional economics in the tradition of Hayek, Buchanan, Coase, North, and Williamson.

\subsection{Key Theoretical Ideas of an Institutional Economic Reconstruction}

An institutional economics analyzes social processes as interactions: how one participant's choice behaviour affects and interrelates with the choice behaviour of other participants of an interaction. Above all, an institutional economics analyzes and aims to resolve interaction conflict or the 'institutional problem'. As North (1993b: 260) formulated: "Institutional theory focuses on the critical problems of human organisation and the problems of achieving cooperative solutions to human interactions". In economic terms, the idea of interaction conflict can be detailed as conflict over capital contributions of an agent to an interaction and the distributions of capital gains from an interaction to an agent. Already the early Simon (1945: Chapter 6), connecting to Barnard (1938), drew on this idea of contributiondistribution conflicts when conceptualizing organizational behaviour (See WagnerTsukamoto 2000a: 138-41). In practical-normative perspective, an institutional economics aims to resolve interaction conflict through the intervention with incentive structures - or "governance structures" in Williamson's terminology, which reflect economics' understanding of the institution and of institutional ordering ${ }^{8}$. Incentive structures set standards or 'rules' regarding both contributions of individual choice makers to an interaction and distributions from an interaction to individuals. So, institutions are strictly interpreted in a situational manner, and interaction problems are intervened in and ordered through a situational incentive logic. Social conflict is thus treated as a situational condition but not as a behavioural condition.

A key issue in modelling interaction conflict is the conceptualization of interdependence amongst the choice behaviour of individual agents (For details see section 2.2. when the idea of the dilemma structure is discussed). A critical consideration here is that individuals participating in social exchange ultimately co-determine through their individual choices - unavoidably, intentionally or unintentionally - outcomes for each individual and for the group as a whole. It is especially the consideration of interdependence which makes the 


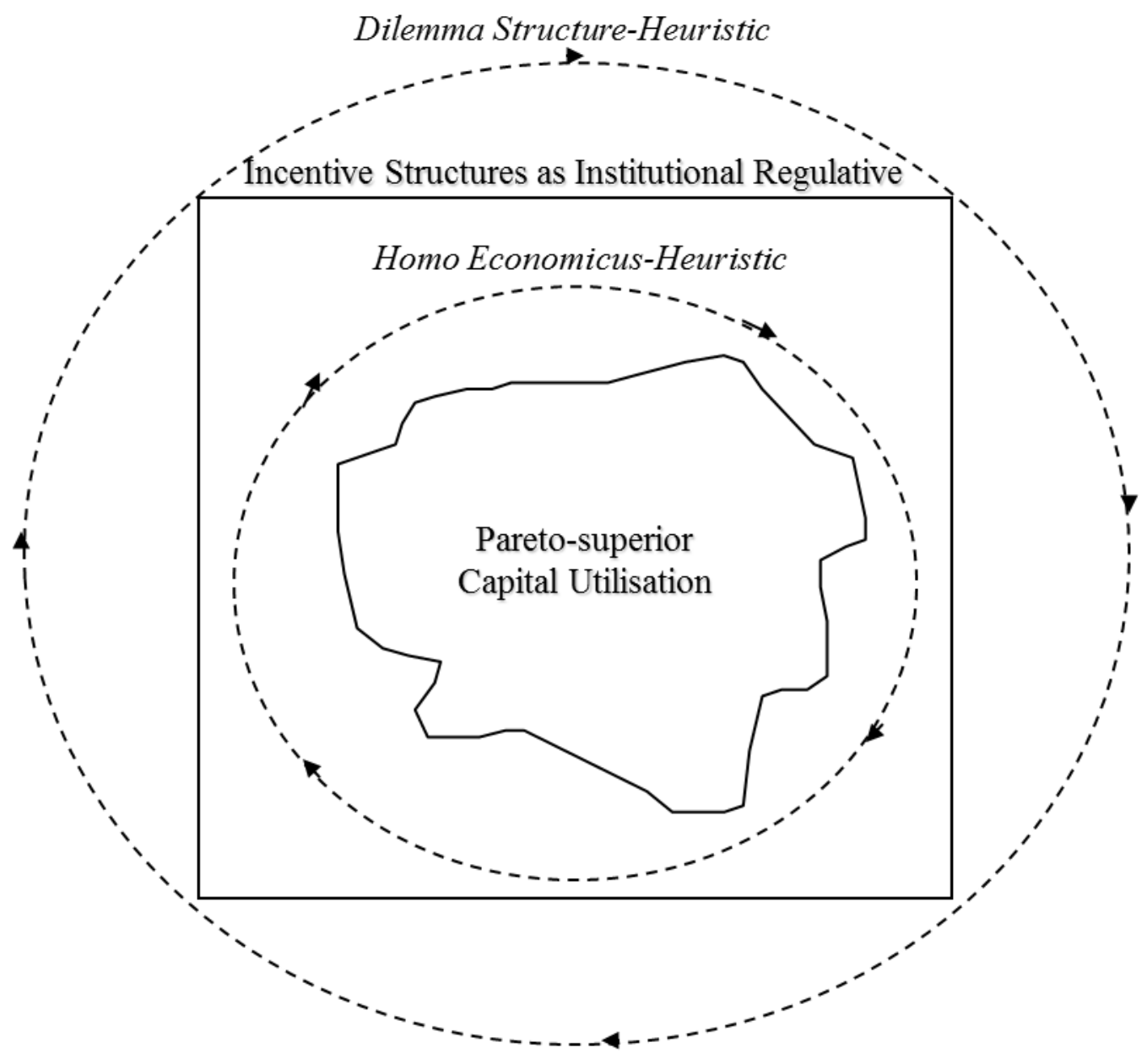

Figure 1. The (Institutional) Economic Approach

conceptualization and resolution of social conflict a non-trivial problem. Game theory discussed this issue in detail (Luce and Raiffa 1957, von Neumann and Morgenstern 1944).

A positive institutional economics analyzes succeeding/failing cooperation in relation to existing incentive structures. Such analysis is subsequently transcended in practical- 
normative perspective. Insights from positive analysis are used to treat the institutional problem as a systemic, situational condition, namely in relation to the (re)-design of incentive structures $^{9}$ - the 'rules of the game' or 'rules structures' or 'governance structures' - in order to encourage cooperation (if desired ${ }^{10}$ ). The studies of Homann (1997: 16-17, 23, 1990: 17 20), Buchanan (1995: 142, 146-7, 1987a: 21-32, 51-63, 1987b: 243), Williamson (1985: 28$29,33-34,72-79)$ provide details on this issue. Stigler and Becker (1977: 76) and early on von Neumann and Morgenstern $(1947: 44,49)$ hinted at this issue, too.

Successful interactions are analyzed in this way as a reflection of incentive-compatible incentive structures, which realign and "equilibrate" (Williamson 1998: 34, 76) individual (self)-interests of interacting choice makers so that mutuality of gains results as interaction outcome. Equally, unresolved conflict and a break-down of cooperation is analyzed as a problem of incentive-incompatible organisation structures, which do not realign interests of (potentially merely) self-interested agents and thus yield mutual loss as interaction outcome, or "rational foolishness", as Sen (1990: 35-7) formulated in behaviouristic terms. Thus, the institutional problem is not treated by an institutional economics by interfering with human nature or 'the human condition', as theology (e.g. Tullock 1981: 42-3, Otzen 1980: 53) and behaviourial sciences do and as is, at times, implied by behavioural economists (e.g. Sen 1990, in degrees even by Williamson, e.g. Williamson 1985: 6). An (institutional) economic research program is likely to be abandoned if the institutional problem were theoretically analyzed in relation to the 'behaviourial make-up' of the individual, e.g. preferences, tastes, values, morals, etc. In practical perspective, a behaviourial approach implies techniques such as value education, social conditioning, conscience training, religious therapy, moral appeal, or preaching, which are not associated with economics (See also Iannaccone 1995: 81-82, 86; Stigler and Becker 1977: 76).

In terms of the practical-normative goal of conflict resolution, an institutional economics analyzes interactions with regard to the goal of pareto-superior capital exchange the creation of mutual gains, of mutual prosperity, of 'common wealth', but not the wealth of a single individual or a small clique of people (See especially Buchanan 1987b: 8, 16, also Wagner-Tsukamoto 2001, Williamson 1998). As Buchanan and Williamson discussed, the idea of mutuality of gains or 'pareto-superiority' reflects the key goal of institutional economic ordering, even of both an 'old' and 'new' institutional economics (e.g. Williamson 
1998: 5 who refers to Commons in this respect). Specific design criteria for intervening with incentive structures in order to ensure pareto-superiority are the generation of paretosuperiority for some time ('stability') and at low cost ('efficiency'). So, incentive structures are to efficiently produce an equilibrium in contribution-distribution interactions (For details, see Wagner-Tsukamoto forthcoming: Chapter 2, 2001). These goals of institutional economic ordering reflect that interacting individuals - despite being (potentially merely) selfinterested $^{11}$ - succeed to cooperate. This was already implied by Mandeville's maxim of "private vices, public good" and Smith's maxim of the "wealth of nations".

\subsection{Key Methodic Ideas of an Institutional Economic Reconstruction}

Methodically, an institutional economics is organized, like any research program, by heuristic tools: in this case, the ideas of the dilemma structure and the homo economicus. They can be viewed as the methodic motor of institutional economics, and probably of economics in general. The dilemma structure reflects economics' model of social interactions. It suggests that interacting choice makers have both common interests - namely to cooperate in order to improve their individual welfare positions -, and conflicting ones - to organize capital contributions to and distributions from an interaction to one's own advantage and to the disadvantage of other agents (Homann 1999: 125-128, 1994: 396-402, 1990: 13, Buchanan 1995: 144-148, Tullock 1985; more incompletely, also Hayek 1976: 79, 1960: 270, Popper 1957: 62, 158). In game theoretical terms, the idea of the dilemma structure models a breakdown of cooperation in a non-zero-sum game, that means all choice makers lose because of non-cooperation - despite the possibility that all choice makers could gain if cooperation succeeded. Williamson (1985: 62-76, 85; also Williamson 1975: 135-6) speaks of the "contracting dilemma", or similarly, Buchanan (1975: 136-42) of the punishment dilemma (Similarly Buchanan 1995: 142-7, 1987b: 42-4, 157). As Williamson (1996: 137) summed 
Figure 2: The Prisoner's Dilemma: Pareto-inferiority

because of self-interested rational choice (regarding

the length of prison sentences; Source: Luce and Raiffa 1957: 95)

Matrix 1

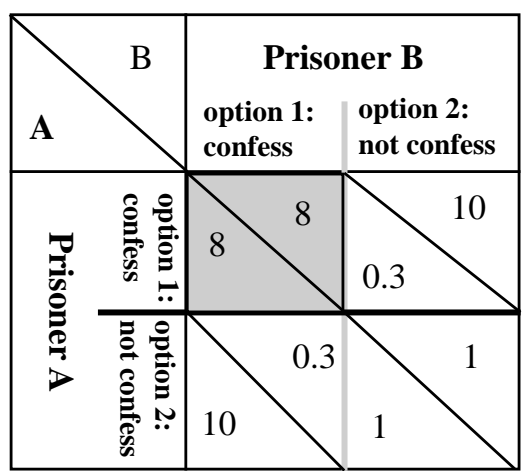

"Rational foolishness" as standard outcome: The group overall loses worst because of self-interested, rational choice (here: in terms of length of prison sentences)

Matrix 2

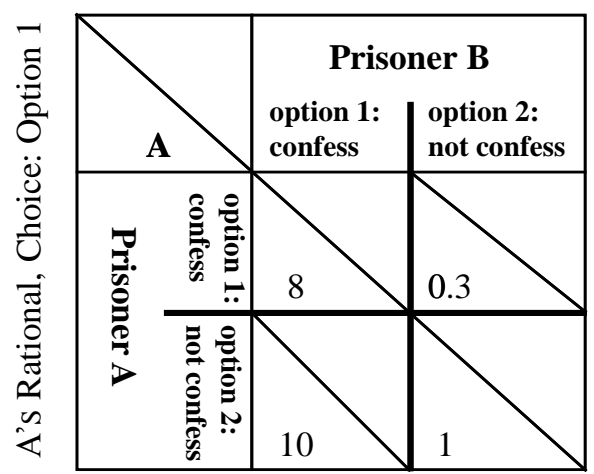

For prisoner A: option 1 dominates option 2

Matrix 3

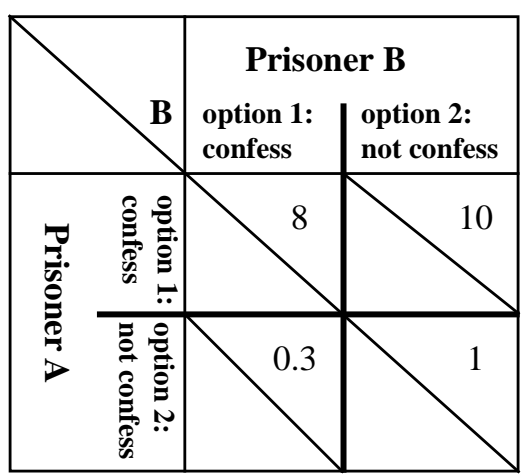

For prisoner B: option 1 dominates option 2 
up, in a dilemma structure "... potential conflict threatens to undo or upset opportunities to realise mutual gains." (emphasis as in original) The prisoners' dilemma and the common's dilemma neatly illustrate such a scenario of interdependent individual choices in which pareto-inferiority emerges as standard interaction outcome (See Hardin 1968: 1244-6, Luce and Raiffa 1957: 94-7, see also Figure 2 and the economic literature on Adverse Selection, Ackerlof-Processes, and Free Riding).

For a normative institutional economics the important implication is here that only if dilemmatic conflicts over capital contributions to and distributions from social exchange can be resolved, can a common interest in achieving gains from cooperation be realized. Otherwise, all interacting choice makers are driven by a 'defective' incentive logic to behave as 'rational fools', which means each individual's (self)-interests are damaged because of selfinterested choice in the face of certain, given incentive structures. Thus, 'rational foolishness' is analytically not attributed to institutions of a different kind, such as defective social values, a deficit in religious predispositions, immoral attitudes, etc., which could be behaviourally handled, for instance, through institutional regulatives such as religiosity and practices of religion (See also Wagner-Tsukamoto 2001). At times, even economists seem to (mis)interpret 'rational foolishness in a non-situational, non-systemic, non-economic, but behaviourial way, e.g. Sen (1990: 30-1, 35-7) and similarly Margolis (1982), Etzioni (1988), and, in degrees, even Williamson (1998: 2, 15-17, 1985: 391).

Importantly, the dilemma structure models an interaction scenario in which cooperation breaks down because of rational self-interested choice, which is modelled through the homo economicus. Compared to the idea of the dilemma structure, the homo economicus is a derivative heuristic of (institutional) economics, supporting and complementing the application of the idea of the dilemma structure. As with the idea of the dilemma structure, the analytical significance and relevance of the homo economicus for (institutional) economic analysis rests strictly on its methodic application (together with the dilemma structure) for analysing, in theoretical perspective, and for improving, in practical perspective, incentive structures and capital exchange. In an empirical-behaviourial sense, the homo economicus is abstracted from human nature (Iannaccone 1995: 77, Homann 1994: 387-92, 395-6, 1990: 9-13, Becker 1993, 1976, Suchanek 1993). Hayek's (1949) concept of "methodological individualism" hinted at this early on. 
A critical issue in understanding why economics applies the methods 'dilemma structure' and 'homo economicus' is the question of the purpose of economic analysis - or problem dependence (Homann 1994, 1990, Suchanek 1994, Homann and Suchanek 1989, Popper 1978, Lakatos 1976; see also above). The ideas 'dilemma structure' and 'homo economicus' have to be strictly understood as methods: tools or "heuristics" in Lakatos' terminology, for analyzing and solving the institutional problem in economic terms, with regard to the (re)-design of incentive structures for improving the pareto-effectiveness of capital exchange. The key insight the dilemma structure and the homo economicus heuristically enable is that non-cooperation "... is inherent in the situation" (Luce and Raiffa 1957: 97), which means in incentive structures that did not realign self-interests of interacting decision-makers. Such a purpose compares to the purpose of Hobbes' concept of the "war of all". He supposedly used this idea in a heuristic sense, too (Homann 1990: 9, 13, also Wagner-Tsukamoto 2001, Buchanan 1987a).

A car crash analogy neatly illustrates this point (See Wagner-Tsukamoto forthcoming, 2001). Like the 'car crash dummy', the homo economicus may not reflect an empirically too realistic portrayal of human nature. So, in terms of the car crash analogy, the dilemma structure can be interpreted as the car crash setting in which an accident is simulated. In real life, car crash dummies are never seen driving cars on roads. But despite being empirically rare, and despite its empirical incorrectness regarding the portrayal of "real people" or "human nature as we know it", to use a key phrase to which behaviourial (institutional) economists, e.g. Williamson (1998: 2, 1985: 6, 391), North (1993a: 14), Sen (1990: 30-1, 357), Coase (1984: 231), Simon (1976: xxi), Knight (1948: 270), claim to subscribe, the crash dummy seems to be rather useful for purposes of car design (but not for improving the driving behaviour of car drivers; this would reflect a different project of social engineering). As the car crash dummy loses its purpose and relevance when separated from the crash test, so the homo economicus does when separated from the dilemma structure and the situational analysis of interaction problems over capital utilization in relation to incentive structures. For the purpose of a theology, an organization psychology, an institutional sociology, or a behaviourial moral philosophy, ideas like the homo economicus and the dilemma structure may be unfruitful and irrelevant research heuristics (See Figure 3). On grounds of problem dependence, they may have to be rejected for this kind of research - but not on grounds of 
being an 'unrealistic' or 'immoral' image of man and world view as implied by some economists and many other social scientists. It is because of its heuristic grounding in the idea of the homo economicus and of the dilemma structure that an economics in the tradition of Mandeville and Smith, as probably most coherently picked up in the 20th century by economists of the likes of Hayek, Friedman, Buchanan, Becker, and Homann, can make considerable moral claims since these heuristics enable the resolution of the institutional problem to the advantage of all choice makers (in more detail, Wagner-Tsukamoto forthcoming: Sections 2.5, 7.1. and 8.1).

\section{An Institutional Economic Reconstruction of Genesis}

The following examines whether and how far the stories of Genesis address the institutional problem in economic terms. The reconstruction proceeds in three steps, tracing in section 3.1. the idea of capital contribution-distribution conflicts and of mutual gains (pareto-superiority) as goals of conflict resolution; examining in section 3.2. the methodic modelling of capital contribution-distribution conflicts through the ideas of the dilemma structure and the homo economicus; and finally, assessing in section 3.3. Genesis' approach to resolving social conflict through institutional ordering via the (re)-design of incentive structures as compared with institutional ordering via the behavioural intervention with value structures. Figure 1 provides a 'road map' for this discussion.

\subsection{Biblical Capital Contribution-Distribution Conflicts and Pareto-superiority as Desired Outcome of Conflict Resolution: In Search of the Genesis of Wealth for a Community of Nations}

In general, Genesis appears not reluctant to analyze social problems through economic concepts of capital utilization and wealth creation. In nearly all biblical stories issues of scarcity regarding certain types of capital, as reflected by capital constraints on choice behaviour, set the scene for cooperation problems. Gordon (1994: 20-1, 1989: 1-3) discussed 
the interest of the Old Testament in issues of scarcity (which is seemingly overlooked by Paris' 1998: 51 assessment of Gordon's studies). Gordon's analysis of scarcity focused on scarce free time ${ }^{12}$ enjoyed by Adam \& Eve in paradise ('six days work/one day off'). The present paper extends such an analysis of scarcity in time capital to other types of capital and, more importantly, projects issues of scarcity on interaction questions of how to handle capital scarcities and the contribution-distribution conflicts it is likely to induce in an interaction.

Ideas of capital and capital utilization can be found in many Bible stories:

- Time capital in terms of "free time" (Gordon 1994: 20-1, 1989: 1-3) but also in terms of "life time" and "eternal life" (Genesis 2: 9, 3: 22, 6: 3).

- Site capital and physical capital in fertile land, drinking water, animals, and plants (Genesis 1: 26, 30, 13: 6-7, 26: 12, 19-24, 27: 28).

- Human capital in terms of knowledge and other skills (Genesis 2: 9, 17, 3: 6, 29: 15, 30: 27) but also in terms of owning people. Even Abraham was seemingly involved in slave trading and slave ownership (Genesis 12: 5, also Genesis 17: 13, 29: 19, 27, 37 : 26-28).

- Inheritance rights and inter-generational capital transfer (Genesis 25: 31, 31: 14).

Bible stories seem typically to approach questions of capital utilisation as interaction conflicts over capital contributions to and capital distributions from an interaction. In Genesis, such interaction conflicts are prominently encountered by Adam \& Eve and God, Abraham and Lot, Abraham and Abimelech, Isaac and Gerar, Isaac and Abimelech, Esau and Jacob, Laban and Jacob, Joseph and the pharaoh of Egypt. These stories have in common that cooperation problems - or the 'institutional problem' - are discussed as interaction problems among a mere handful of persons. Such a scenario in which only a small number of persons interact compares to the analytical approach of the theories which form the conceptual backbone of an institutional economics, namely game theory, property rights theory, principal-agent theory, and a transaction cost economics. Besides enabling a detailed 
discussion of interaction problems, a small numbers focus analytically reflects that only in an interaction context with a finite number of agents can social conflict, which is caused by interdependent choice behaviours, arise (In detail Homann 1999; also Williamson 1985, 1975; Luce and Raiffa 1957; von Neumann and Morgenstern 1944). Conceptually and practically, however, the Bible, like a constitutional and institutional economics, is seemingly not interested in cooperation problems among a mere handful of people. Bible stories typically examine the resolution of interaction problems amongst tribes or nations - which are personified through their leaders.

Interaction problems in the "city" (Genesis 11: 4, 22: 18, 44: 3), the "nation" (Genesis 10: 1-32, 12: 2, 18: 18, 27: 29), and even a "community of nations" (Genesis 35: 11, 48: 4, 19, also Genesis 18: 18, 22: 18) are targeted. They reflect cooperation problems in modern social arenas: where anonymity and value pluralism potentially reign in social interactions and traditional institutional mechanisms of social ordering, e.g. family-type bonding and value sharing, can be expected to be largely ineffective (Discussed in detail in section 3.3. as the 'condition of modernity'; see also Wagner-Tsukamoto 2001). Such an inter-group focus which hints at institutional analysis for modern contexts becomes equally apparent when the "Table of Nations" is set out in chapter 10 of Genesis, or when the final stories of Genesis culminate in a large-scale migration story, with the Israelites relocating as expatriates to their affluent neighbour Egypt, and subsequently large-scale conflict emerging between the two nations (See Wagner-Tsukamoto 2000a).

The Bible's favoured strategy for conflict resolution can be characterized as an economic, 'capitalistic' one: not peace or harmony in social relations as such is the goal of conflict resolution, as theology possibly might expect (e.g. Tullock 1981: 45, Lace 1972: 106; see also Figure 3), but the creation of wealth for all choice makers (Genesis 14:11,17-24), in a sense of 'economic peace' or 'industrial peace'. Normative ideals like the wealth of a city (Genesis 11: 4, 22: 18), the wealth of a nation (Genesis 10: 1-32, 12: 2, 18: 18, 27: 29), and even the wealth of a community of nations (Genesis 35: 11, also Genesis 18: 18, 22:18) strongly hint at such an economic rationale for handling the institutional problem. In the more technical economic speak of Buchanan and Williamson, mutuality of gains and paretosuperiority were seemingly advocated as goal for resolving conflict. Even Abraham, one of the few role models in Genesis who reflected a value adhering man who had succeeded to 


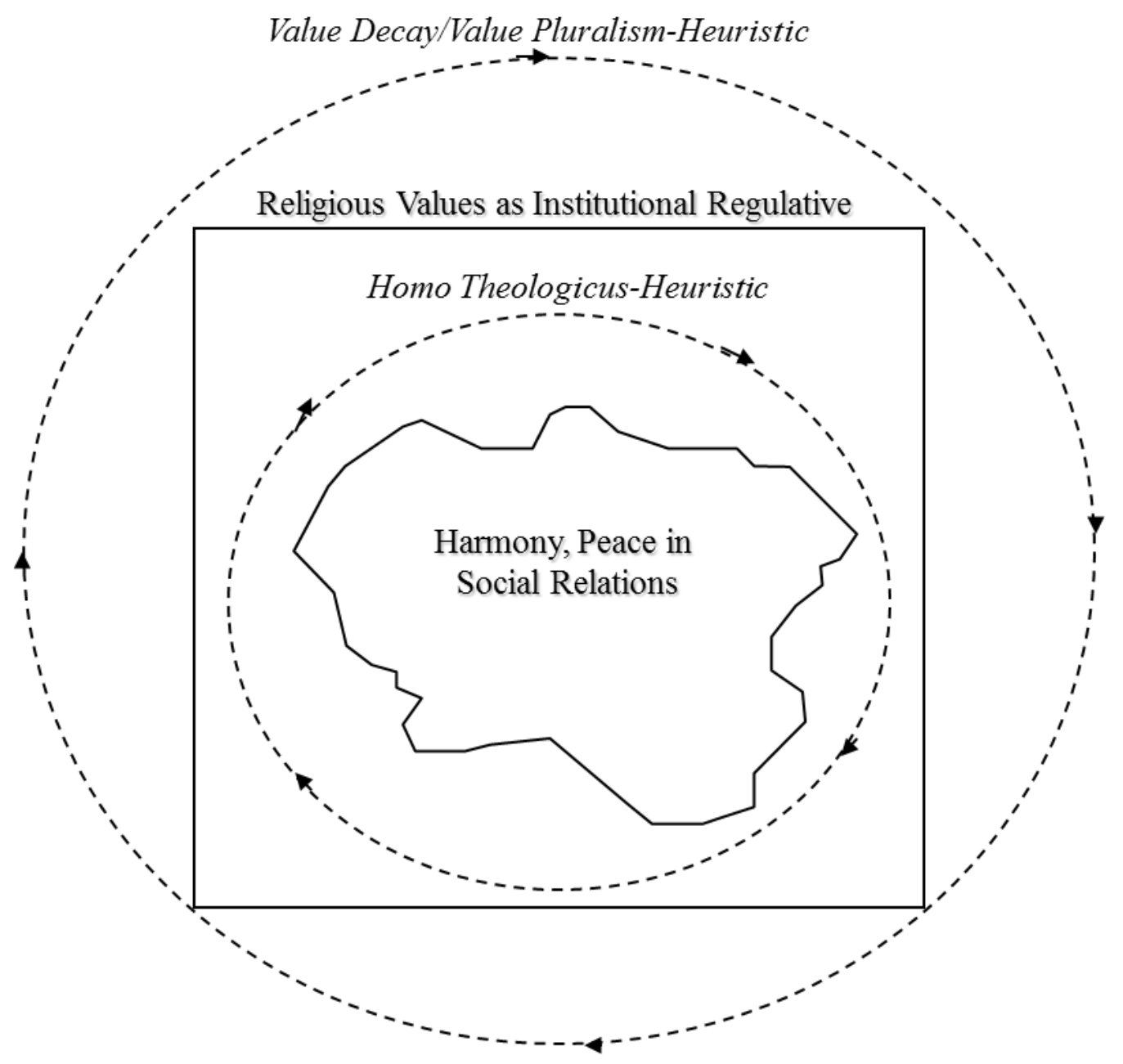

Figure 3. Behavioural Approaches: The Theological Approach 
live a godly life was rewarded with increases in wealth: he "... had [in the wake of his emigration to Egypt] become very wealthy in livestock and in silver and in gold." (Genesis 13: 2, also 24: 34-35, 53) Such biblical themes compare in considerable degrees to Adam Smith's suggestions on the Wealth of Nations: gains from social interactions over capital utilization were to be shared amongst all agents ${ }^{13}$. Otherwise, as Smith pointed out, social exchanges could not be expected to materialize (See also Tullock 1985).

An apparent analytical interest of the Bible in examining the institutional problem in economic terms can be related to the specific historic-economic context in which the Bible emerged, with the condition of modernity (i.e. value pluralism) being encountered in full force. Even up to today, questions over the utilisation of scarce resources, like land and water, have remained a burning issue in the hot climate and desert-stricken areas of the Near and Middle East. Taken together with the high economic development of certain areas in this region in biblical times, e.g. in Egypt (See Tullock 1981: 22-8, Ap-Thomas 1972: 11, 24, also Cohn 1981: 2) - which opened up affluence differentials with neighbouring regions and thus was likely to induce migration ${ }^{14}$-, social conflict and cooperation problems amongst migrating tribes and societies could be expected to surge. Also, keeping in mind an institutional regulation function of religion, it was probably no coincidence that ultimately three world religions emerged from the very same area of the Near and Middle East, where seemingly severe contribution-distribution problems over certain resources had raged since

ancient times ${ }^{15}$. The thesis can be advanced here that, possibly for the first time in mankind's long history, (1) the institutional problem was encountered under the condition of modernity, with value pluralism, with even value decay prevailing, and (2) a (documented) attempt was made to advise through the stories of the Bible on cooperation problems. As section 3.3. details, in the face of rising value pluralism, the Bible seemed to favour economic ordering via incentive structures over behaviourial ordering via value structures, such as religious belief systems.

\subsection{A Methodic Interpretation of Defection in Paradise: The Biblical Analysis of Contribution-Distribution Conflicts Through the Ideas of the Dilemma Structure and the Homo Economicus}


From the very first story in which social problems are discussed in the Bible, in the garden of Eden story, an interest in contribution-distribution conflicts is indicated. In the garden of Eden story, Adam \& Eve committed the 'original sin': they appropriated fruits from the tree of knowledge which belonged to God and were as a result evicted from paradise (Genesis 3: $6,15-19)$. One may ask why the authors of the Bible chose this dramatic scenario of failing cooperation in paradise to start biblical story telling.

Gordon's (1994: 20-1, 1989: 1-3) discussion of scarcities in time capital, namely in relation to the amount of work time Adam \& Eve had to allocate to keeping paradise cultivated, which curtailed their free time, reflects on a capital contribution problem encountered by Adam \& Eve in paradise. Questions of capital distribution arose in paradise, too: the garden of Eden story details a property rights arrangement of how goods or 'capital' were distributed between the 'principal' God and the 'agent' man. Adam \& Eve were promised that they could make use of nearly any plant, animal, and land in paradise. They were 'only' forbidden to approach the tree of knowledge and the tree of eternal life. These trees were God's (Genesis 2: 16-17, 3: 22-24). Thus, Adam \& Eve could not utilise the most valuable assets of paradise - the trees "... in the middle of the garden ..." (Genesis 2: 9). These capital contribution-distribution arrangements begin to illumine why interaction problems between God and Adam \& Eve could occur at all: contributions-distribution problems loomed 'even' in paradise. Indeed, they defined paradise. Seemingly an economic conceptualization of 'paradise' drives the biblical analysis of cooperation problems. In a practical-normative perspective, this implies the need to prevent and resolve contributiondistribution conflicts in order to preserve paradise (Section 3.3. examines how the Bible proceeded in this respect). In contrast to many tribal religions, the Bible is rather modern in this respect, modelling as a starting point of a discussion of social problems severe capital constraints on choice behaviour, with contribution-distribution conflicts arising regarding a scarcity in knowledge and wisdom and a scarcity in longevity or time. Such capital constraints appear central to the Bible's understanding of paradise: Adam \& Eve could only choose within a constrained decision space. They did not live in a land of Cockaigne or a 'fool's paradise', as a land of Cockaigne - a land of unlimited choice and no constraints - is also poignantly referred to. Such constraints on choice behaviour in paradise regarding fruits 
from certain trees were not identified by Gordon's $(1994,1989)$ and Paris' (1998) studies of issues of scarcity in biblical thought.

In dramatic fashion, the Bible thematically raised this issue through Adam \& Eve's original sin the failure to resolve contribution-distribution conflicts (with subsequent Bible stories consistently returning to this theme; see sections 3.1. and 3.3). It can be suggested that the Bible invoked the scenario of defection and of a break-down of cooperation in paradise largely for analytical reasons: it heuristically enabled the Bible's analysis of the institutional problem. The original sin may 'just' provide a heuristic in the Lakatosian sense (See section 2.2), methodically instructing and organizing theory building (in the case of the Bible: the analysis of social conflict). In this respect, the original sin compares, both regarding its conceptual nature and regarding a methodic theory building function in institutional analysis, to Hobbes' idea of the war of all, or more abstractly, to the idea of the dilemma structure (as discussed in section 2.2). In the following, an apparent application of the idea of the dilemma structure in the Garden of Eden story is further discussed. The discussion proceeds in two steps: first, the idea of a contribution-distribution dilemma is identified in the Garden of Eden story, and subsequently, its likely heuristic, methodic status in biblical story telling is elaborated on.

On the one hand, Adam \& Eve and God had a common interest to maintain good interactions since this benefited both with regard to improving their respective welfare positions, Adam \& Eve being allowed to utilize paradise and keep most fruits generated in the course of the cultivation of paradise, and God getting and keeping earth cultivated while preserving his privileged access to the trees of knowledge and life. But on the other hand, conflicting interests existed, too, namely regarding the specific split of capital contributions to and distributions from their interactions, especially with regard to the trees of knowledge and of eternal life which exclusively belonged to $\operatorname{God}^{16}$.

When assessing the interaction outcomes in the garden of Eden story, at least in imagery terms albeit not necessarily in strict game theoretical ones, Adam \& Eve and God seemingly behaved as 'rational fools': Adam \& Eve suffering the eviction from paradise and God suffering the loss of intellectual property in sole knowledge. Such a loss/loss outcome can be interpreted in institutional economic terms with regard to the specific incentive structures which framed interactions in paradise ${ }^{17}$. If one looks at the way incentive structures 
incurred gains and losses as a result of defection, Adam \& Eve faced big incentives to defect, namely to acquire privileges which came with the position of being 'God': of intellectual capital in the form of knowledge and wisdom ${ }^{18}$. Besides gains, Adam \& Eve could also expect certain losses as a result of defection. Letting Adam \& Eve get away unpunished after a first defection was not a rational option to God since Adam \& Eve could then be safely expected to defect further by eating from the tree of life, thus becoming truly like God. A rational Adam \& Eve would have anticipated sanctions after a first defection, but to what extent? Despite the threatened sanction to be killed for defecting, which would have rendered their theft valueless and yielded 'rational foolishness' even in strict game theoretical terms (pareto-inferiority), Adam \& Eve probably could expect that killing was not a rational option to God to sanction defection: it would have implied the loss of 'human capital', and consequently devalued God's 'investments' into the creation of the earth, his knowledge of good and evil (since, after killing man, nobody would be left who potentially could act in an evil manner) as well as his sole access to unlimited time capital (since a 'competitor' for time would no longer be around). A less severe sanction, like the eviction from paradise, may thus not have come unexpected to Adam \& Eve. Whether Adam \& Eve's defection could be classified as 'rational foolishness' in strict game theoretical terms (as pareto-inferiority), meaning that overall they (as well as God) lost more than they gained as a result of their choice behaviour, depends on how Adam \& Eve valued the gain from defection - knowledge - as compared to loss resulting from defection - eviction from paradise ${ }^{19}$.

The key purpose of modelling defection in paradise and of invoking the idea of the original sin can be suggested to be a heuristic one: the original sin methodically instructing the analysis of the possibility of defection in capital exchange, the possibility of a "war about goods", as Genesis $(14: 2,11,16)$ later details. Through the idea of the "fallen condition of man" and a "continuous struggle" (Gordon 1989: 1, 3), social exchange could be simulated by the Bible as a potentially conflict-laden interaction over capital contributions and distributions. The prospect of "... if war breaks out ..." (Exodus 1: 10, emphasis added) could be analysed in this way. Thus, like Hobbes' idea of the war of all, or more abstractly, the concept of the dilemma structure in institutional economic analysis, the idea of the original sin may reflect a methodic instrument of the Bible for raising and analyzing the institutional problem. Such an instrumental interpretation of the original sin differs from an empirical- 
behavioural one, as theology (e.g. Tullock 1981: 42-3, Otzen 1980: 53) and also a behavioural, theologically grounded economics suggest (e.g. Gordon 1994, 1989, also Paris 1998).

A non-behavioural, methodic answer to the question of why the Bible invoked the idea of the original sin is supported by the way Genesis (and the other books of the Bible) sequenced and extended an analysis of contribution-distribution problems, when at times the idea of the dilemma structure is explicitly touched upon (1) through the common's dilemma, as reflected, for instance, by the stories of how Lot and Abraham as well as Isaac and Gerar (Genesis 13: 6-9, 26: 19-24) encountered shepherding problems in relation to scarce land and water, and (2) also through the prisoners' dilemma, as reflected by the story of the exodus of the Israelites form Egypt which yielded mutual suffering as interaction outcome (WagnerTsukamoto 2000a). A methodic interpretation of the original sin is further supported by how a resolution of cooperation problems was worked out in Bible stories: not so much behaviourally in relation to the human condition (as theology might expect) but nonbehaviourally in relation to a situational condition of defective incentive structures (Section 3.3. follows up), advocating the changing of incentive structures, such as property rights arrangements for land and water usage.

Similarly, the idea of self-interested choice may merely play an important heuristic role in Bible stories. Already in the garden of Eden story, self-interested choice behaviour is prominently modelled (1) by splitting assets between God and Adam \& Eve with certain assets remaining the sole property of one party, and (2) by invoking a calculus of self-interest through a speaking snake which appeals to Adam \& Eve to appropriate God's assets (Genesis 3: 13$)^{20}$. Adam \& Eve's self-interested choice behaviour and related the snake metaphor could be (mis)-interpreted as an image of man-reference, as modelling human nature as "opportunistic" and "self-seeking with guile", as Williamson (1998: 1, 1985: 6, 30-32, 64-67, 1975: 26-30) behaviourally (mis)-interprets the idea of self-interest for an institutional economics $^{21}$. It can be asked why the snake remained the only speaking animal in biblical story telling. Possibly, by invoking a speaking animal the Bible wanted to quite explicitly prevent a behaviourial (mis)-interpretation of a calculus of self-interest as a reference to human nature (Aesop's fables seem to proceed similarly). By projecting self-interest on a speaking animal, Genesis may stress a methodic, heuristic role of a calculus of self-interest in 
institutional analysis, hinting at its empirical-behavioural irrelevance for analyzing cooperation problems. Such a methodic role of a calculus of self-interest (as of the idea of the dilemma structure) in the analysis of the institutional problem can be compared to the instrumental role of the car crash dummy in the accident simulation setting of the car crash test (See section 2.2. above).

Thus, when subsequent stories of the Bible discuss self-interest as evil, wickedness, sinfulness, etc. (Genesis 6: 5, 8: 21, 13: 13, 42:22) or "venality and faithlessness" (Raskovich 1996: 450), this may have to be interpreted as an instrumental, methodic application of the homo economicus - even if at times a foreground behaviourial (mis)-interpretation of selfinterest can be found in the Bible, such as God being quoted to say that "... every inclination of his [man's] heart is evil from childhood ..." (Genesis 8: 21). Such statements should not be taken as an empirical-behavioural depiction of human nature. Indeed, if this were done by theology or a behavioural, theologically grounded economics, this would imply a stark and disturbing image of human nature in these research programs. Biblical statements about selfinterest and "sinfulness" may be better transcended regarding a heuristic status in instructing the analysis of the institutional problem. The Bible may here merely imply that capital contribution-distribution interactions were to be analyzed under conditions "if": "if war breaks out" (Exodus 1: 10), and related, "if man behaved self-interested" ("being tempted by the snake").

\subsection{Biblical Ordering and Conflict Resolution: Favouring Incentive Structures and Economic Institutions Rather Than Value Structures and Behavioural Institutions?}

Sections 3.1. and 3.2. identified an apparent theoretical and methodic interest of Bible stories in analyzing the institutional problem in economic terms. An important remaining question in an institutional economic reconstruction of Bible stories is how institutions, social structures which could resolve conflict and encourage cooperation, were conceptualized by the Bible. Was behaviourial, theological-psychological ordering, via institutions such as value structures and religious belief systems, preferred? Or was economic ordering, via institutions such as incentive structures, preferred? Two rather different types of institutions for resolving social 
conflict and inducing cooperation can be distinguished in this way:

(1) Social values, morals, virtues, religious belief. They reflect behavioural theological, sociological, psychological - institutions which are behaviourally enacted by being intrinsically shared amongst choice makers, e.g. through practices of religiosity. If well enacted, they nearly instinctively pre-dispose choice makers towards cooperation in social exchange.

(2) Incentive structures or "the economic institutions of capitalism", as Williamson (1985) termed them. They reflect social structures which, if well enacted, systemically realign self-interests amongst choice makers by means of allocating contributions and distributions to interacting choice makers in a way so that cooperation emerges on grounds of self-interested choice.

Conceptually and practically, these different types of institutional mechanisms reflect rather different approaches to institutional analysis - behavioural analysis versus economic analysis (See also Figures 1 and 3).

In general, a contractarian approach appears highly fruitful for conceptualizing the institutional problem. Indeed, both behavioural institutional analysis and economic institutional analysis can be thought of as being grounded in a contracting model behavioural contracting versus economic contracting among agents. Institutional treatises as diverse as Hobbes' Leviathan or Rawls' Theory of Justice can be thought of as subscribing to a contracting model when analyzing the institutional problem. Similarly, elements of a contractarian approach can be made out in the Bible: In Hebrew, the very idea of 'God' is interpreted as a "central contracting host", as "sovereign over all the hosts" whereby "hosts" are understood as God's "powers", "armies" (See the Preface, p. 50, of Gideon's edition of the Bible, 1984) ${ }^{22}$. The following examines how Genesis conceptualized institutional ordering and especially the role of God as contracting host: 'hosting' behavioural value contracting over religious belief or 'hosting' economic contracting over incentive structures. It is suggested that social ordering in relation to economic institutions was increasingly favoured by the Bible as the stories of Genesis unfold ${ }^{23}$. 


\subsubsection{Genesis' Behaviourial Approach to the Institutional Problem: A Psychological- Theological Contract Between God and Man and the Religiosity of the Individual as Institutional Regulative}

At least in some of the early stories, Genesis seemed to aim theoretically and practically at value contracting in order to handle the institutional problem, namely when it invoked a "covenant" even an "everlasting covenant" (Genesis 9: 8, 12, 17: 4-7, 19, 17: 7, 19, 22:18) between God and man, which was grounded in man's faith in God (See Spriggs 1974:4). Through stories which depicted role models of highly religious men, nearly 'holy man', the Bible indicated how man should aim to live in the image of God, adhering to social values such as righteousness, justice, non-violence (Genesis 4: 7, 6: 9-11, 22, 9: 6, 20: 6, 22: 15). Key role models discussed in this respect were Noah, "a righteous, blameless man" (Genesis 6: 9), and Abraham, a "right and just man" (Genesis 18: 19). The resolution of social problems was thus approached in a behavioural manner, being made dependent on the clear conscience of the individual, as reflected by the religiosity of man and his personal mastery of living in the image of God. The Bible's approach compares in this respect to a social psychology ${ }^{24}$, and similarly to a behaviourial ethics, e.g. a virtue ethics, which suggests that through the "... [behavioural] regulation of the individual soul ..." (Plato 1999: 174), namely by leading a godly life, the institutional problem can be solved, in Plato's words, the "... good and true city and state ..." can be achieved (Plato 1999: 174).

But even when the Bible seemingly favoured such a behaviourial route to institutional analysis it still backed up conflict resolution with certain methods and concepts of economics. This is reflected by the type of interaction outcome that was discussed for value contracting: not peace or harmony in social relations as such but the generation of wealth for all choice makers. Even the good religious man received ample capital distributions from social interactions: for living in the image of God, Noah and Abraham and their families (their 'nations') were rewarded with fruitful land, prosperity, longevity, and surviving disasters (See also section 3.1. above $)^{25}$. From the very beginning, Genesis signalled such an economic framework for behavioural contracting when man's living in the image of God was interlinked 
with "ruling" over capital: "God said: 'Let us make man in our image, in our likeness, and let them rule over the fish of the sea and the birds of the air, over the livestock, over all the earth, and over all the creatures that move along the ground." (Genesis 1:26) The question of how to effectively "rule" over capital was answered by Genesis with the recommendation of value contracting with God: faith in God and living a life in the image of God. Genesis seemed to propose here that, in line with man approximating an image of God, an institutional regulative could be enacted for organizing successful capital utilization. In this respect, Genesis' positive suggestions on man being created in the image of God may have to be normatively interpreted in the first place.

It seems quite clear that Genesis was not written as a pure behaviourial ethics: at least it aimed at a "behaviourial economics", questions of value contracting between God and man being tied to issues of effective capital utilisation and economic rewards. The Bible apparently viewed religiosity and value contracting as means for effective capital utilisation. The subsequent discussion details whether and, if so, how far Genesis qualified such an approach. It is suggested that Genesis set out proposals on 'truly' economic institutional ordering, favouring economic ordering over value contracting. The subsequent discussion proposes that such a switch in perspective can be explained with respect to a superior capability of economic institutions to handle cooperation problems for certain interaction contexts, namely modern ones (See section 3.3.2).

\subsubsection{Genesis' Exit From a Behavioural-Theological Economics: The Birth of Israel and the Favouring of Economic Ordering as Mechanism for Institutional Regulation}

Effectiveness and efficiency limits of behavioural ordering are likely to be reached in certain interaction contexts, namely when the condition of modernity is encountered, which means when value pluralism ${ }^{26}$, or negatively formulated, a lacking value consensus and even value decay, characterize social interactions ${ }^{27}$. In social arenas such as the city, the nation state, and the more so a community of nations, value contracting and the maintenance of a value consensus may become too difficult and too expensive (Wagner-Tsukamoto forthcoming: Chapter 1 and 8, 2001, also MacIntyre 1985: 1-5, Hardin 1968: 1246). Possibly the Bible 
initially entered only a behavioural ethics (supported by a behaviourial economics) in order to qualify such an approach in relation to the condition of modernity. The fragility of value contracting was already hinted at in the garden of Eden story, but the more so through various family-type interaction scenarios (Cain-Abel, Jacob-Esau, Jacob-Isaac, Joseph-his brothers, etc.) in which value contracting normally would be expected to succeed (or at least be more cost-effective than economic ordering $)^{28}$ - but still failed.

In contrast to behavioural ordering via an intrinsically enacted value consensus, a ('conventional': 'non-behaviourial', 'situational') economics analyzes interaction problems as problems of pareto-effective capital utilization in relation to economic institutions, namely incentive structures of one form or another. The advantage of such an approach is that it can solve the institutional problem while tolerating the condition of modernity at the same time. As it emerged in force from Buchanan's studies and more implicitly also from Williamson's, interaction problems over capital contributions and distributions - the potential "war about goods" in the Bible's terminology - can probably be more successfully handled in this way, both theoretically and practically. The condition of modernity was thematically invoked by the Bible through the tower of Babel story (chapter 11); through the story of the destruction of Sodom and Gomorrah (chapter 19) and, probably most importantly, through the stories of Jacob struggling with Esau, Laban, and God, and Jacob being subsequently re-born as "Israel" ${ }^{29}$. Genesis began to discuss in detail the limits of a behavioural ethics to handle social conflict under the condition of modernity through the story of the destruction of Sodom and Gomorrah. In this story, a value consensus had broken down and value decay was emerging. In this situation, behavioural institutional intervention could only resort to an apocalyptic, religious fundamentalist approach to 'solve' the institutional problem - by raining “... down burning sulphur" (Genesis 19: 23) on Sodom and Gomorrah which wiped out these cities ${ }^{30}$. Such conflict 'resolution' reflects the theoretical and practical exhaustion of behaviourial institutional analysis when the condition of modernity is encountered (See also WagnerTsukamoto 2001). The Bible seemed to be very much aware of such shortcomings of a behavioural ethics to solve the institutional problem constructively. This is reflected by how Genesis developed a discussion of the institutional problem after the Sodom and Gomorrah incident. Especially in the stories of Jacob's struggle with Esau, Laban, and God (as discussed in the following), and in the in-depth 'case study' of the epic struggle over 'industrial justice' 
between Egypt and its expatriate Israelite work force (See Wagner-Tsukamoto 2000a), the Bible seemingly sought a conceptual re-orientation which enabled a constructive resolution of social conflict under tolerance of value pluralism or even value decay.

Genesis (chapters 30-31) depicts Jacob as being inclined towards deceitfulness and cheating. He is modelled as a choice maker who is not instinctively pre-disposed towards cooperation in social interactions (as earlier invoked by Genesis through the figures of Abraham and Noah). Jacob's behaviour closely reflected the homo economicus. He knew how to bend and interpret a contract to his advantage without breaking it. For instance, exploiting an emergency situation when his elder brother was close to starving, Jacob "enticed" Esau to sell his birth right to him (Miller 1994:759). Later, again under awkward circumstances, Jacob extracted from his father Isaac an agreement which allowed him to 'cash' in the rights which he had 'bought' from Esau. Jacob's knowledge of haggling tactics, of "perfunctory cooperation" or "organizational misbehaviour", as Williamson (1985: 262-3, 1975: 68-70, 801) or Ackroyd and Thompson (1999: 1-3, 25) might call it, becomes the more apparent in interactions with his employer Laban. A classic contribution-distribution conflict, reflecting the commons dilemma, is told here by Genesis (30: 31-43 and 31: 1-2, 3-24, 26, 38-42). Besides the payment of a fixed wage by Laban to Jacob, Jacob and Laban agreed to share capital gains from farm production: their contract detailed that Jacob was allowed to keep all newly bred speckled and spotted sheep and goats of Laban's herd. However, since Jacob was the shepherd and thus the producer of livestock capital he could influence through clever breeding tactics the number of spotted and speckled animals. The agreement between Jacob and Laban did not explicitly forbid Jacob to follow such tactics. A problem of so-called "incomplete, relational contracting" existed, as Williamson (1985: 71-79) might put it. This opens up room for discretionary employee behaviour (See also Wagner-Tsukamoto 2000b; Williamson 1967, Berle and Means 1932). Once Laban discovered that Jacob had exploited a contractual grey area, he could not do much about it: in this specific instance, God - the central contracting host - explicitly forbade him to settle the dispute in a violent, physical manner (Genesis 31: 24, 42). Rather, Laban was forced into a new contract with Jacob which settled the conflict by changing incentive structures: by setting out new property rights to shepherding (Genesis 31: 44, 52). This seemed to ensure pareto-superior capital utilization over time. 
Related to the story of Jacob's interactions with Laban, but possibly even more revealing regarding a conceptual reorientation of institutional analysis in Genesis, the story of God's failing chastisement of opportunistic Jacob hints at the limits of value contracting under the condition of modernity. In dramatic figurative fashion, Genesis illustrated this in the story of God turning into man, fighting with Jacob, and losing to Jacob:

"So Jacob was left alone [by his servants], and a man wrestled with him till daybreak. ... Then the man said, 'Let me go, for it is daybreak.' But Jacob replied, 'I will not let you go unless you bless me.' The man asked him, 'What is your name?' 'Jacob,' he answered. Then the man said, 'Your name will no longer be Jacob, but Israel, because you have struggled with God and with men [Esau, Laban] and have overcome."' (Genesis 32: 24-28)

Limits of solving 'struggles' in social interactions through value contracting are seemingly spelled out. Like MacIntyre (1985), Genesis seems to ask here what comes After Virtue, more precisely: after the limits of a behaviourial ethics (even if supported by a behaviourial economics) have been reached. The apparent conclusion developed by Genesis through the stories of the struggles between Laban and Jacob and between God and Jacob is that for solving the institutional problem in the face of value pluralism ${ }^{31}$, theological-psychological contracting should no longer be favoured. For maintaining the integrity of a behaviourial ethics it could even be argued that to let God lose to Jacob was a necessity: only in this way was 'God', understood as the idea of unconditional good, of 'humanity' in a very noble sense, theoretically and practically left intact; otherwise, God had to take on the role of a value driven 'terrorist' who could only 'solve' the institutional problem in a radically destructive way, as depicted in the story of Sodom and Gomorrah. This reflects a desperate but also a highly emancipatory and coming of age message of Genesis: man seems to be called upon to solve conflicts and cooperation problems without (primarily or solely) relying on value contracting and the maintenance of a value consensus as it was promoted in the stories involving Abraham and Noah. Seemingly the Bible pointed out in this way that under certain circumstances social ordering via religiosity was unsuccessful and too costly (or at least less successful and more costly than economic ordering). Not surprisingly, the story of God's fight with Jacob ultimately finds an economic solution in Genesis: unlike his forefathers Abraham 
and Noah, who were still given land by God for showing faith in God and living a godly live, Jacob bought land and paid for it with money earned from his interactions with Esau and Laban, so setting up his nation: "For a hundred pieces of silver, he bought ... the plot of ground where he pitched his tent. There he set up an altar and called it El Elohe Israel." (Genesis 33: 19-20)

Besides the stories involving Jacob, Genesis already hinted at similar economic proposals for conflict resolution when Abraham and Lot split up land (Genesis 13: 6-9), when Jacob and Esau split up land (Genesis 36:6-8), or when Jacob compensated Esau for the 'theft' of his birth right by making payments to him (Genesis 32: 13-15, 33: 10-11). Also, the treaty of Beersheba between Abraham and Abimelech, later renewed between Isaac and Abimelech (Genesis 21: 22-31, 26: 19-23), settled a dispute on the use of water through the design of incentive structures: a rule - here a sworn oath, a "promise" - on how the dispute was to be settled, and a sanction - here: a payment of seven lambs by Abraham to Abimelech - to sanction the rule. Not through a behavioural value contract via God as contracting host but through incentive structures, (re)-designed by man through "private ordering" and "governance", to use Williamson's (1985: 9-10, 28-29, 33-34, 72-79) terms, were cooperation problems solved. The 'situation' and thus a systemic condition was interfered, with but not human nature or the human condition (via religiosity and living a godly life in the case of theology).

Even from the very outset, the Bible hinted how, in the face of value pluralism and value decay, cooperation could still be assured - in economic terms through incentive structures: after Adam \& Eve's defection "... he [God] placed on the east side of the Garden of Eden cherubim and a flaming sword flashing back and forth to guard the way to the tree of life." (Genesis 3: 24) Potential conflict was here no longer tried to be solved in a pre-modern, tribal manner through intrinsic, behavioural contracting and the handling of the human condition, e.g. by trying to strengthen the religiosity of man. Rather economic institutions, including economic sanctions, were drawn upon. "Cherubim and a flaming sword" or, more pragmatically expressed, certain costs (benefits) allocated to an agent in the wake of failing cooperation (succeeding cooperation) actually changed calculated gains and losses of decision makers in a way which made cooperation in social interactions self-enforcing on grounds of self-interest. 
By pointing towards economic ordering as a means of solving the institutional problem, the Bible so probably showed more insight and wisdom than the suggestions of many behaviourial researchers, including behaviourial economists, who often analyze and try to solve cooperation problems under the condition of modernity by focusing too narrowly on the individual's value system as institutional regulative. Social interaction dynamics which cause the "self-elimination of conscience", of religiosity, of virtues, etc. in a modern context (Wagner-Tsukamoto 2001, Hardin 1968: 1246; sensed by MacIntyre 1985: 1-3), as they were seemingly anticipated by the Bible, are then overlooked, as cost considerations are ignored regarding value contracting and the maintenance of a value consensus when the condition of modernity is encountered $^{32}$. 
Cost of institutional ordering/

contracting

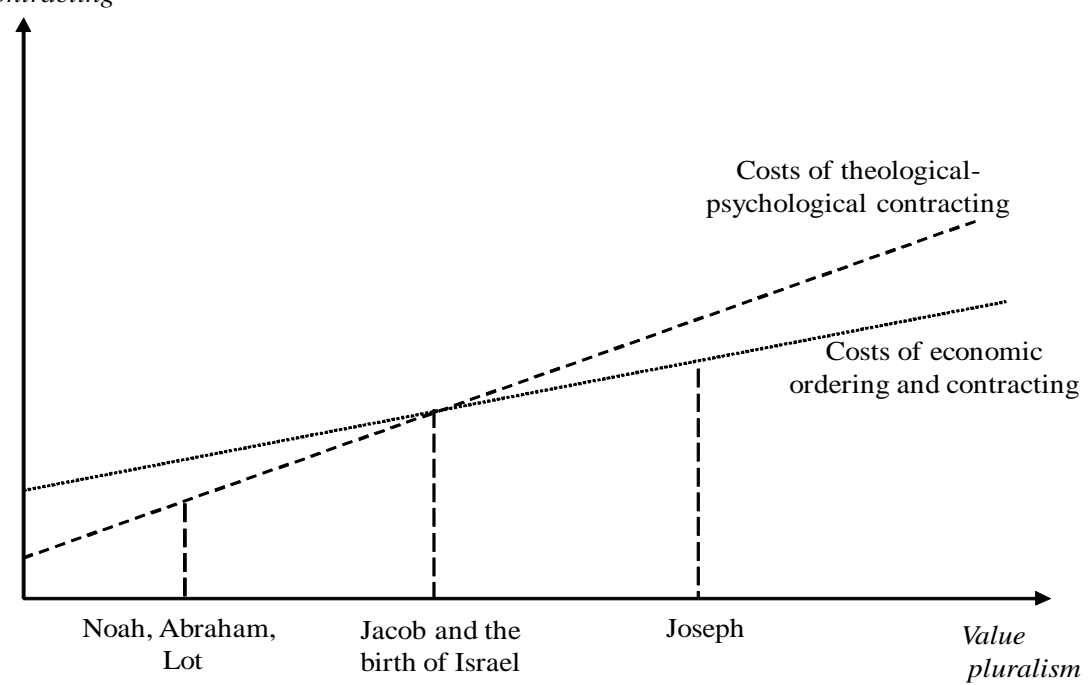

Figure 4

Onset of Modernity (Value Pluralism)

\section{Conclusions on the Economic Origins and Economic Nature of Biblical Thought}

There appears to be ample room for interpreting Bible stories in institutional economic terms with reference to capital contribution-distribution conflicts, mutuality of gains in social interactions, and incentive structures as institutional regulative. Such an analysis of the Bible has hardly begun. The few existing economic interpretations of the Bible are either micro- 
economically oriented, applying the theoretical approach of rational choice theory, or analyze Bible stories through a religious, theologically grounded economics rather than an economics of religion. An institutional economics, as outlined in this paper, enables a different, more integrated and possibly more fundamental economic analysis of Bible stories: it examines in theoretical-practical perspective how far the Bible positively and normatively handles the institutional problem as a capital contribution-distribution conflict in relation to incentive structures and methodically grounds such analysis in the idea of conflict-laden interactions (the dilemma structure) and the idea of self-interested choice behaviour (the homo economicus). Findings of such an economic reconstruction of the Bible compare in considerable degrees to Adam Smith's Inquiry into the Wealth of Nations - making more plausible why the moral philosopher Adam Smith ultimately switched from a behavioural ethics to a (non-behavioural) economics for investigating social problems of modern society.

The narrative sequence and the message emerging from the stories of Genesis raises the question of how far the Bible already sensed the approach of a constitutional and institutional economics, as was pioneered by Hayek, Buchanan, Coase, North, and Williamson. In relation to invoking the condition of modernity, of value pluralism, even of value decay, the Bible seemed to carefully resist calling upon God, understood in a behavioural institutional sense, to solve cooperation problems, apparently realizing that in social arenas like the city, the nation, and the international community, theologicalpsychological ordering reflected a pareto-inferior strategy for conflict resolution. Then Genesis no longer advocated behaviourial techniques like value education, or even "value indoctrination" and "social conditioning" as behaviourial economists suggest (e.g. Sen 1990: 36, Simon 1976: 103, 149-51; also Etzioni 1988; in degrees even Williamson 1998: 15-17). And neither did Genesis then advocate any longer a destructive Sodom-and-Gomorrah-type approach for restoring the effectiveness of behavioural institutions and value contracting. Behaviourial institutions like religiosity may only be capable of effectively and efficiently solving the institutional problem in a pre-modern context, for intra-group interactions within socially highly cohesive and behaviourally strongly bonded social units, such as a traditional family or a tribe ${ }^{33}$.

Theology could probably take issue only with an economic reconstruction of biblical stories if the status of economics as a moral social science were questioned or misunderstood 
and, possibly related, methods of economic analysis, e.g. the homo economicus, were (mis)interpreted in empirical-behavioural perspective as references to human nature and a world view. The paper stressed that, on grounds of a proper understanding of the problem dependent nature of economic research as well as theological research, an economic interpretation of Bible stories is still likely to be compatible with a religious world view and a religious image of man, although certain (new) adjustments to and modifications of religious and theological thinking may become necessary ${ }^{34}$. Growth in scientific knowledge nearly always implies the qualification of traditional knowledge. In a nearly Nietzschean tradition, the Bible seemed to sense this: "For with much wisdom, comes much sorrow: the more knowledge, the more grief." (Ecclesiastes 1: 18)

The article also hinted that the question can be raised regarding how far JudeoChristian religion is grounded in a capitalist ethics. Such an examination complements, possibly in degrees even revises, Max Weber's analysis of a religious ethic of capitalism. Related, the spread of certain religions as world religions can be explored in economic terms.

Admittedly, this paper focused on the big questions of an economic deciphering and reconstruction of the Bible. Future research has to deepen the lines of analysis that were marked out. An in-depth economic reconstruction of individual stories of the Bible as well as an in-depth tracing of different conceptual ideas appears promising, such as the Bible's analysis of scarcity and the relationship of scarcity to the condition of modernity; biblical suggestions on the derivation of property rights; the role of contractarianism in biblical thought, especially incomplete, relational contracting; the economics of biblical law-making, law enforcement, and jurisdiction; the self-elimination, adverse selection dynamics of religiosity when encountering a "Jacob"; types of contractual and non-contractual economic institutions conceptualized in the Bible; fiscal policy in biblical thought; etc. For the purpose of such analyses, the scene seems to be set conceptually by an institutional economics which recognizes methodic and theoretical differences in comparison to theology, and similarly, to a behavioural, theologically grounded economics. An institutional economics, understood in this way, conducts positive analysis with a view to normative analysis, namely the (re)-design of incentive structures in order to solve capital contribution-distribution conflicts to the mutual advantage of interacting parties (or differently put, the genesis of the wealth of nations), thus preventing a potential "war about goods" as Genesis invoked in a Hobbesian 
tradition. 


\section{Bibliography}

Ackroyd S. and Thompson P. (1999), Organizational Misbehaviour, London: Sage.

Anderson, B. W. (1966), The Living World of the Old Testament, London: Longman.

Ap-Thomas, D. R. (1972), "The Context of the Old Testament", in O. J. Lace (ed.), Understanding the Old Testament, Cambridge: Cambridge University Press, 11-100.

Becker, G. S. (1993), "The Economic Way of Looking at Behavior", Journal of Political Economy 101, 385-409.

--- (1976), The Economic Approach to Human Behavior, Chicago, Ill: The University of Chicago Press.

--- (1965), "A Theory of the Allocation of Time", The Economic Journal 75, September, 493517.

Benner, A. (1997), "Religious Institutions and the Economics of Religion", Journal of Institutional and Theoretical Economics 153, 1:150-158.

Berle, A. A. Jr. and Means, G. C. (1932), The Modern Corporation and Private Property, New York: Macmillan.

Brennan, H. G. and Waterman, A. M. (1994), "Introduction: Economics and Religion?", in H.

G. Brennan and A. M. Waterman (eds), Economics and Religion: Are They Distinct?, Boston: Kluwer, 3-15.

Brams, S. J. (1980), Biblical Games: A Strategic Analysis of Stories of the Old Testament, Cambridge, MA: MIT Press. 
Buchanan, J. M. (1995), "Individual Rights, Emergent Social States, and Behavioral Feasibility", Rationality and Society 7, 2:141-150.

--- (1987a) Economics: Between Predictive Science and Moral Philosophy, College Station: Texas A\&M University Press.

--- (1987b), "The Constitution of Economic Policy", American Economic Review 77, 243250.

--- (1975), The Limits of Liberty. Between Anarchy and Leviathan, Chicago, Ill: University of Chicago Press.

Cassirer, E. (1962), Leibniz' System, Hildesheim, Germany: Georg Olms.

Coase, R. H. (1984), "The New Institutional Economics", Journal of Institutional and Theoretical Economics 140, 1:229-231.

Cohn, R. L. (1981), The Shape of Sacred Space: Four Biblical Studies, Chico, Cal.: American Academy of Religion (AAR)/Scholars Press.

Ensminger, J. (1997), "Transaction Costs and Islam: Explaining Conversion in Africa", Journal of Theoretical and Institutional Economics 153, 1: 4-29.

Etzioni, A. (1988), The Moral Dimension. Towards a New Economics, New York: Free Press.

Friedman, M. (1953), Essays in Positive Economics, Chicago: The University of Chicago Press.

Gordon, B. (1994), "Theological Positions and Economic Perspectives in Ancient Literature", in H. G. Brennan and A. M. Waterman (eds) Economics and Religion: Are They Distinct?, 
Boston: Kluwer, 19-40.

--- (1989), The Economic Problem in Biblical and Patristic Thought, Leiden and New York: Brill.

Hardin, G. (1968), "The Tragedy of the Commons", Science 162, 1243-48.

Hardin, R. (1997), "The Economics of Religious Belief", Journal of Theoretical and Institutional Economics 153, 1: 259-278.

Hayek, F. (1976), Law, Legislation and Liberty: The Mirage of Social Justice, Volume 2, London: Routledge \& Kegan Paul.

--- (1960), The Constitution of Liberty, London: Routledge \& Kegan Paul.

--- (1949), Individualism and Economic Order, London: Routledge \& Kegan Paul.

Hodson, G. (1967), The Hidden Wisdom in the Holy Bible, London: Theosophical Publishing House.

Homann, K. (1999), "Zur Grundlegung einer modernen Gesellschafts- and Sozialpolitik: Das Problem der Sozialen Ordnung", in U. Blum, W. Esswein, E. Greipl, H. Hereth and S. Müller (eds) Soziale Marktwirtschaft im nächsten Jahrtausend, Stuttgart, Germany: SchäfferPoeschel, 119-148.

--- (1997), "Sinn und Grenze der ökonomischen Methode in der Wirtschaftsethik", Volkswirtschaftliche Schriften 478, 1-42.

--- (1994), "Homo oeconomicus und Dilemmastrukturen", in H. Sautter (ed.) Wirtschaftspolitik in offenen Volkswirtschaften, Göttingen, Germany: Vandenhoeck \& Ruprecht, 387-411. 
--- (1990), "Ökonomik und Ethik", Conference Paper, 5th Symposium "Kirche heute", 11-13 October 1990, Augsburg, Germany.

Homann, K. and Suchanek, A. (1989), "Methodologische Überlegungen zum ökonomischen Imperialismus", Analyse \& Kritik 11, 1:70-93.

Knight, F. H. (1948), Risk, Uncertainty and Profit, 3rd edition, Boston: Houghton.

Iannaccone, L. R. (1998), "Introduction to the Economics of Religion", Journal of Economic Literature 36, 3:1465-1495.

--- (1995) "Voodoo Economics? Reviewing the Rational Choice Approach to Religion", Journal for the Scientific Study of Religion 34, 1:76-89.

Kuran, T. (1994), "Religious Economics and the Economics of Religion", Journal of Institutional and Theoretical Economics 150, 4:769-775.

Lace, O. J. (1972), "The History of Religion in Israel", in O. J. Lace (ed.), Understanding the Old Testament, Cambridge: Cambridge University Press, 101-177.

Lakatos, I. (1976), The Methodology of Scientific Research Programmes, Cambridge: Cambridge University Press.

Luce, R. D. and Raiffa, H. (1957), Games and Decisions. Introduction and Critical Survey, New York: J. Wiley.

MacIntyre, A. (1985), After Virtue, London: Duckworth.

Margolis, H. (1982), Selfishness, Altruism and Rationality, Cambridge: Cambridge University Press. 
Miller, G. P. (1994), "The Legal-Economic Approach to Biblical Interpretation", Journal of Institutional and Theoretical Economics 150, 4:755-762.

--- (1993a), "Contracts of Genesis", Journal of Legal Studies 21, 15-45.

--- (1993b), "Ritual and Regulation: A Legal-Economic Interpretation of Selected Biblical Texts", Journal of Legal Studies 21, 477-501.

Muller, J. Z. (1993), Adam Smith in His Time and Ours, Princeton, N.J.: Princeton University Press.

Neumann, von, J. and Morgenstern, O. (1947), Theory of Games and Economic Behavior, Princeton, NJ: Princeton University Press.

North, D. (1993a), "Institutions and Credible Commitment", Journal of Institutional and Theoretical Economics 149, 1:11-23.

--- (1993b), "Institutions and Economic Performance", in U. Mäki, B. Gustafsson and C. Knudsen (eds) Rationality, Institutions and Economic Methodology, London: Routledge, 242261.

Otzen, B. (1980), "The Use of Myth in Genesis", in B. Otzen, H. Gottlieb, and K. Jeppsen (eds) Myths in the Old Testament, London: SCM Press, 22-61.

Paris, D. (1998), "An Economic Look at the Old Testament", in S. T. Lowry and B. Gordon (eds) Ancient and Medieval Economic Ideas and Concepts of Social Justice, New York: Brill, 39-103.

Plato (1999), The Essential Plato, translated by B. Jowett, Uxbridge: Softback Preview. 
Popper, K. (1978), Conjectures and Refutations. The Growth of Scientific Knowledge, London: Routledge and Kegan Paul.

Raskovich, A. (1996), "You Shall Have no Other Gods Beside Me: A Legal-Economic Approach of the Rise of Yahweh", Journal of Institutional and Theoretical Economics 152, $3: 449-471$.

Schein, E. (1980), Organizational Psychology, London: Prentice-Hall.

Sen, A. K. (1990), "Rational Fools: A Critique of the Behaviourial Foundations of Economic Theory", in J. J. Mansbridge (ed.), Beyond Self-interest, Chicago, Ill: University of Chicago Press, 25-43.

Simon, H. A. (1976), Administrative Behavior, 3rd revised edition, New York: Free Press.

Smith, Adam (1976), An Inquiry into the Nature and Causes of the Wealth of Nations, 2 Volumes, Oxford: Clarendon.

Smith, I. (1999), "The Economics of the Apocalypse: Modelling the Biblical Book of Revelation", Journal of Institutional and Theoretical Economics 155, 3:443-457.

Spriggs, D. G. (1972), Two Old Testament Theologies: A Comparative Evaluation of the Contributions of Eichrodt and von Rad to Our Understanding of the Nature of Old Testament Theology, London: SCM Press.

Stolz, F. (1974), Interpreting the Old Testament, London: SCM Press.

Suchanek, A. (1994), Ökonomischer Ansatz und theoretische Integration, Tübingen, Germany: Mohr-Siebeck.

--- (1993), "Der homo oeconomicus als Heuristik", Working Paper No. 38, Department of 
Management and Economics, Catholic University of Eichstaett at Ingolstadt, Germany.

Stigler, G. J. and Becker G. S. (1977), "De Gustibus Non Est Disputandum", American Economic Review 67, 2:76-90.

Tullock, G. (1985), "Adam Smith and the Prisoners' Dilemma", Quarterly Journal of Economics 100, 1073-1081.

Tullock, J. (1981), The Old Testament Story, Englewood Cliffs, NJ: Prentice-Hall.

Wagner-Tsukamoto, S. A. (forthcoming), Human Nature and Organization Theory, Cheltenham: Edward Elgar; revised version of The Image of Man in Organization Theory. On the Institutional Problem and the Portrayal of Human Behaviour in the Social Sciences, Doctoral Dissertation, July 2000, Department of Management and Economics, Catholic University of Eichstaett at Ingolstadt, Germany.

--- (2001), "The Failure of the Quaker Experiments (1900-1940) in Corporate Social Responsibility: Implications for an Economic Approach to Business Ethics", Conference Paper, EBEN-Conference, 9-10 April 2001, University of Nottingham, Nottingham, UK; publication forthcoming.

--- (2000a), "The Exodus of the Wealth of Nations: The Disequilibration of Interests Between Egypt and Israel and the Emergence of 'Rational Foolishness' in Social Interactions", Revised Version of Discussion Paper No. 2000/05, Management Centre/Department of Economics, University of Leicester, UK, April 2000; publication forthcoming.

--- (2000b), "An Institutional Economic Reconstruction of Scientific Management: On the Lost Theoretical Logic of Taylorism", Discussion Paper No. 2000/14, Management Centre, University of Leicester, UK, December 2000; publication forthcoming.

Williamson, O. E. (1998), "Human Actors and Economic Organization", Conference Paper, 
7th Biannual Meeting of the International Joseph Schumpeter Society, June 1998, Vienna, Austria.

--- (1996), "Economics and Organization: A Primer", California Management Review 38, 2:131-146.

--- (1985), The Economic Institutions of Capitalism, New York: Free Press.

--- (1975), Markets and Hierarchies. Analysis and Antitrust Implications, New York: Free Press.

--- (1967), The Economics of Discretionary Behavior: Managerial Objectives in a Theory of the Firm, London: Kershaw.

${ }^{1}$ The question of whether and how far divine inspiration was involved in the writing of the Bible probably only poses an interesting research problem for theology (and a theologically grounded economics) but less so for scientific research which, grounded in the tradition of the Enlightenment, would question metaphysics as the basis of rational argument.

${ }^{2}$ An institutional economics, as interpreted in this paper, comprises a constitutional economics and the 'new' institutional economics. Constitutional ordering is interpreted by the present paper as a special type of institutional ordering. Historically, a constitutional economics, as pioneered by Hayek and Buchanan (also North), preceded the development of a 'new' institutional economics, as it is particularly linked to Williamson (also Coase). In the following, whenever the term "institutional economics" is used it refers to both a constitutional and a 'new' institutional economics.

${ }^{3}$ Brams (1980: 177) concluded that a game theoretical reconstruction did not yield a "magic key" to understanding the essence of biblical story telling.

${ }^{4}$ As a by-product of the subsequently led discussion, questions are addressed regarding the respective distinctiveness of economics and theology, as initially raised by Hardin and Waterman (1994).

${ }^{5}$ Even more generally, the idea of God could be interpreted as a principle of social ordering. Hodson (1967: 93) points out that the original Hebrew term used for "God" in Genesis (Elohim) refers to "order of creative, evolutionary intelligence" but not to a personal God as many later translations and interpretations of the Bible imply. If one abstracts such an understanding of "God" further, it probably can be linked to principles of organized and self-organizing social order as it permeates the writings of an institutional economics (and institutional studies in general).

${ }^{6}$ In the debate regarding a "literalist" versus "source-critical" theological approach (Paris 1998: 39, Tullock 1981: 9-13) to analyzing the Old Testament, the institutional economic reconstruction pursued by the present paper is closer to a source-critical approach than to a literalist one. Sourcecritical researchers analyze the Bible as a purely man-made text whereas literalist researchers assume 
that the Old Testament reflects the words of an omnipotent and omnipresent personal God. As much as the present paper and source-critical theological research approach questions of authorship similarly, an economic interpretation of biblical thought as developed in this paper still differs considerably from a source-critical theology, namely with regard to the methodical and theoreticalpractical interpretation of the substance of biblical thought.

${ }^{7}$ Over time theology seems to have at least implicitly acknowledged that such ontological claims made to and derived from the Bible are untenable. This is reflected by its acceptance that physical or biological theories, e.g. on the origin of the world or the evolution of life, are compatible with the Bible (although it could be suggested, as implied by the present paper, that the Bible is not predominantly interested in physical and biological research problems).

${ }^{8}$ Based on the positive-theoretical analysis of social problems, an institutional economics, like economics in general, advises practitioners like managers or politicians on institutional ordering and the design of institutional structures. Economics from the studies of Mill, Bentham, Pareto to the studies of Knight, Hayek, Buchanan, North or Williamson have always had such a strong practicalnormative orientation. As Popper (1957: 56) noted by referring to Hayek: "Economic analysis has never been the product of detached intellectual curiosity about the why of social phenomena, but of an intense urge to reconstruct a world which gives rise to profound dissatisfaction." (See also Williamson 1998: 1-2, Homann 1997: 16-17, 23, Muller 1993: 1-2, North 1993b: 253-5, Becker 1993: 402, Buchanan 1987b: 16-17, 21-32, 51-63).

${ }^{9}$ The idea of the institution is here interpreted as incentive structures. Section 3.3. has further details.

${ }^{10}$ Indeed, in the simple example of the prisoners' dilemma, as discussed in section 2.2, noncooperation among the prisoners is desired by society. Incentive structures are here deliberately set up to make the prisoners behave as 'rational fools'. This implies that a normative institutional economics can aim at inducing cooperation but also non-cooperation - depending on what is viewed as socially desirable. The concept of competition in a market economy be interpreted similarly, which, if properly enacted, forces individual firms to behave as non-cooperative 'rational fools'-for the larger good of society (See also Wagner-Tsukamoto 2001).

${ }^{11}$ In this respect, a key advantage of an economic approach over a behavioural approach to handling cooperation problems is that it can tolerate value pluralism, even value decay in social interactions, and can still induce socially desirable interaction outcomes. Thus, it conceptually and practically accommodates the "condition of modernity" (value pluralism, value decay) without having to overcome it in order to solve the institutional problem (For details, see Wagner-Tsukamoto 2000a, 2001; see also section 3.3. below).

${ }^{12}$ Becker (1965) would speak of "time capital".

${ }^{13}$ Smith discussed as an ordering mechanism the "invisible hand", i.e. the incentive structure "price mechanism", although he proceeded in a more governance-oriented contractarian, institutional economic tradition in chapter 6 on the Treaties of Commerce amongst nations (Smith 1976).

${ }^{14}$ Indeed, regarding its linguistic roots, the word 'paradise' is of Persian origin. Fascinating in this respect is Otzen's (1980) comparison of the garden of Eden story to Babylonian narratives, such as the Gilgamosh epic (See also Tullock 1981: 43-4).

${ }^{15}$ However, how far religious belief systems can possibly solve interaction conflicts of agents who subscribe to different sets of religious belief (value pluralism!) has to be examined critically (See section 3.3).

${ }^{16}$ Otzen (1980: 45) tends to imply wrongly that man was prevented from achieving eternal life as a result of being driven out of paradise. As discussed above, already in paradise man was forbidden to eat from the tree of eternal life: this constraint on Adam \& Eve's choice behaviour 
reflects the very essence of the garden of Eden story and how the Bible conceptualised 'paradise'.

${ }^{17}$ As further detailed below, such a substantive-theoretical interpretation of the original sin should be projected to a likely methodic purpose of the original sin in the Bible's analysis of social problems.

${ }^{18}$ And if the first defection regarding the tree of knowledge succeeded, defection could be extended to the tree of life, with the prospect looming of acquiring unlimited time capital (See also Genesis 3: 22-24).

${ }^{19}$ That means the diagnosis of a loss/loss outcome for all interacting decision makers, of paretoinferiority, depends on the way Adam \& Eve make this assessment (God lost as a result of Adam \& Eve's defection anyway).

${ }^{20}$ The snake-metaphor is explicitly reconnected to in Exodus (7: 8-13, also 4: 3-4, 17), seemingly again, in order to draw special attention to the disastrous effects of self-interested choice in interactions in a dilemma structure (Wagner-Tsukamoto 2000a: Section 3.1). Also, the question can be raised why Adam \& Eve should trust the ruler 'God' regarding his promise that Adam \& Eve were allowed to keep fruits (except the ones from the tree of knowledge and tree of life) which their cultivation efforts of paradise yielded. North's (1993a: 14) ruler-constituent analogy is here instructive (See Wagner-Tsukamoto forthcoming: Section 4.1, 2000b). Adam \& Eve's defection can in this respect be interpreted as a pre-emptive counter-defection (See also Hardin 1968: 1244-6 on the "self-elimination of conscience" in the commons dilemma).

${ }^{21}$ A parallel behavioural (mis)-interpretation could be suggested regarding a self-interested image of God in relation to the property rights arrangements concerning the tree of knowledge and the tree of eternal life.

${ }^{22}$ Even inter-generational contracting amongst nations - an idea prominently discussed in Rawls' Theory of Justice - was seemingly touched upon when Genesis (9: 12) invoked a "covenant for all generations to come". A focus on inter-generational contracting is also reflected by the accounts of lengthy family trees in the Bible (e.g. Genesis 5: 3-32, 10: 1-31, 11: 10-30, 25: 1-19, 36: 1-40, 46: 8-25).

${ }^{23}$ An apparent dialectic in the Bible between a 'behaviourial economics' and a ('conventional': 'non-behaviourial', 'situational') economics can be further explored with regard to questions of authorship of the Bible, which are debated in the theological literature regarding different groups of authors: avowed economically oriented Yahwists and avowed spiritually oriented Elohists (Gordon 1994: 19-21). In this respect, it could be examined whether Elohists were as 'non-economically' oriented as claimed: they may have pursued 'at least' a behaviourial economics (See section 3.3.1). In general, an institutional economic analysis of the Bible could shed new light on questions of authorship by focusing first on the why of authorship, asking what basic problems motivated the writing of the Bible before the who of authorship is re-examined. Possibly, theology has paid in this respect too much attention to the question of authorship in its own right. Absence of conclusive findings on questions of authorship despite centuries of theological research seems to underline this. For the interpretations developed in this paper, the question of authorship was intentionally sidelined: the author who had the 'last word' on the writing of the Bible, as reflected by the way the Bible presents itself to us today, provides the implicit reference point for questions of authorship.

${ }^{24}$ Schein (1980: 22-24, 98-101) would here speak of "psychological contracting".

${ }^{25}$ Besides linking psychological contracting to an economic concept of rewards, it could be suggested that behavioural contracting was further economically backed up with a sacrifice model which could economically test contract commitment: here, value commitment. Such a test was prominently discussed through the Bible story of God requesting Abraham to sacrifice his only son Isaac (Genesis 22: 1-3). To a degree, this compares to a hostage model for analyzing and ensuring 
effective contract execution, as elaborated on in an institutional economics (Williamson 1985: 169175). Miller's (1993b) interpretation of Bible stories with regard to a sacrifice model can be linked in this way to institutional economic analysis. Raskovich's (1996: 462) analysis of religious services in biblical times through a franchise model is instructive here, too.

26 "Liberty", as Mill might call it. Questions regarding the quality of morality of a behaviourial ethics as compared with an economic approach to ethics can be raised here, too (See WagnerTsukamoto 2001).

${ }^{27}$ The historic-economic environment in which the Bible emerged and the social conflicts it reflected probably closely mirrored problems of value pluralism (Briefly hinted at above in section 3.1). A crucial biblical example here is the inter-national, multi-cultural interaction scenario discussed in the story of Israel in Egypt (See Wagner-Tsukamoto 2000a).

${ }^{28}$ Seemingly, the Bible was rather critical regarding family bonds being an effective institutional (behavioural) regulative, as reflected by the interaction problems depicted through family feuds.

${ }^{29}$ Also, the stories involving Joseph, as well as Moses, have to be considered here when the role of the condition of modernity in biblical thinking is discussed (See Wagner-Tsukamoto 2000a).

${ }^{30}$ Plato (1999: 1317-18) rather similarly suggested protectionism, the banning of international travelling, and even a "war for values" as means to ensure the effectiveness of value contracting as an institutional behavioural regulative. For a behavioural ethics, such as a virtue ethics and a religious ethics, some rather grim moral implications emerge from such suggestions (See Wagner-Tsukamoto forthcoming: Chapter 8, 2001).

${ }^{31}$ In the story of God fighting with Jacob, Genesis hinted at value pluralism and the condition of modernity by explicitly locating the fight "... within sight of the city" (Genesis 33:18) - with the "city" being a key reference to value pluralism, even value decay, at least since Genesis' discussion of the Sodom and Gomorrah incident. detail.

${ }^{32}$ Figure 4 captures hypotheses which future research has to spell out further and examine in

${ }^{33}$ In certain isolated instances, such a pre-modern context may have survived even in industrial societies as, for example, illustrated by the Amish people in the USA.

${ }^{34}$ With lessons learnt from discourses with natural sciences over the past centuries, theology may possibly be prepared to engage more openly in such discourses with social sciences. 